\title{
Nulidad del planeamiento urbanístico e invalidez de los actos amparados en el mismo. Atención especial a las nuevas iniciativas legislativas al respecto
}

\author{
Andrés M. González Sanfiel (España) \\ Universidad de La Laguna \\ asanfiel@ull.es
}

\section{NOTA BIOGRÁFICA}

Doctor en Derecho por la Universidad de La Laguna, Premio Extraordinario de Doctorado. Profesor Titular de Derecho Administrativo. Entre sus líneas de investigación se encuentran el régimen de las infraestructuras, los servicios de interés económico general y el Derecho urbanístico, materia en la que es Investigador Principal del Proyecto de la Agencia Estatal de Investigación Nuevo Derecho Urbanístico (DER-2017-84387-P).

\section{RESUMEN}

La nulidad de los planes está generando múltiples problemas por la aplicación de la teoría de la nulidad absoluta. La doctrina y la sociedad reclaman un cambio de esta situación, tal y como lo han hecho otros países. El plan debe ser protegido por el extraordinario valor que tiene para el tráfico jurídico.

\section{PALABRAS CLAVE}

Planeamiento; nulidad; límites; cambios legislativos.

\begin{abstract}
The rules of nullity applied in case of illegal plans carry out a lot of problems. Doctrine and society are claiming legislative changes as soon as possible, in the same ways than other countries. Planning should be protected due to its extraordinary value of legal affairs.
\end{abstract}

\section{KEYWORDS}

Urban planning; nullity; limits; legislatives changes.

\section{SUMARIO}

1. LA NULIDAD DEL PLANEAMIENTO: UN PROBLEMA NACIONAL. 2. RADIOGRAFÍA Y PATOLOGÍAS DE UN SISTEMA FORMALISTA A LA LUZ DE LA JURISPRUDENCIA. 3. LA SENDA DE FLEXIBILIZACIÓN EMPRENDIDA POR OTROS PAISES. 4. LOS ACTOS FIRMES NO SE TOCAN. LÍMITES A LA REVISIÓN DE OFICIO. 5. CAMBIAR EL MODELO JERÁRQUICO Y ENTRELAZADO DE PLANES Y DE ACTOS RESPECTO DE LOS PLANES. 6. LA NECESARIA INTERPRETACIÓN FUNCIONAL DE LOS REQUISITOS FORMALES. 7. EL VALOR NORMATIVO DE LO FÁCTICO A PESAR DE LA NULIDAD DEL PLAN. 8. EL NUEVO PAPEL DEL JUEZ DE LO CONTENCIOSO. 9. SOBRE LA REFORMA «NON NATA»: LAS TRES «ERRES» DE LA INVALIDEZ. 10. UN CAMBIO ESTÁ LLEGANDO. BIBLIOGRAFÍA. 


\section{LA NULIDAD DEL PLANEAMIENTO: UN PROBLEMA NACIONAL}

Hace sólo unos días se acaba de confirmar la nulidad del plan general de la ciudad en la que vivo. El alcalde, acompañado de los representantes de las organizaciones empresariales, daba una rueda de prensa intentando transmitir confianza a la ciudadanía y a los inversores ante la desaparición del mundo del derecho de la citada norma ${ }^{1}$. No es una situación aislada, puesto que pocas ciudades se han librado del llamado «efecto radioactivo» de la nulidad de los planes ${ }^{2}$. La situación se agrava por el hecho de que, anulado el plan, también dicha nulidad se proyecta sobre los planes de desarrollo o derivados, así como los múltiples actos administrativos que a lo largo de la vigencia del plan anulado se han venido sucediendo en el tiempo (efecto cascada o en cadena). Todo el equilibrio de intereses que representa al plan, tras tortuosos años de tramitación administrativas, caen por tierra y, con él, las licencias, los proyectos de urbanización, los convenios y todos los actos jurídicos que se sustentan en aquellos planes. Es una situación preocupante.

La incertidumbre se apodera de la gente de la noche al día: ¿se pueden continuar las promociones y viviendas en marcha? ¿Las obras públicas previstas en el plan se pueden seguir ejecutando? ¿En qué situación queda mi vivienda? ¿Se pueden dar nuevas licencias? ¿Se puede solicitar una hipoteca para comprar una vivienda en la ciudad cuyo plan ha sido anulado?

En efecto, los planes concilian una multiplicidad de intereses complejos, públicos y privados, al que se llega tras largos años de tramitación y esfuerzo colectivo. Las medias de aprobación de los planes o sus modificaciones son de récord, pero por lo que tardan. Una vez aprobados, establecen un orden que sirve de base, a su vez, a la aprobación de nuevos planes y a la realización de la diversidad de actos jurídicos que se apoyan en los mismos. La Administración, la ciudadanía, los promotores, la colectividad en suma, confía en esa cobertura normativa para desarrollar las obras, usos y actividades que aquella ordenación les sirve de soporte (actos administrativos, compraventas, alquileres, préstamos hipotecarios, desarrollo de actividad empresarial, implantación de infraestructuras y dotaciones colectivas, etc.). El valor que ese instrumento tiene para la sociedad es incalculable: actos jurídicos que se suceden a lo largo de los años y que generan la confianza en un tráfico jurídico en el que se sustenta la vida colectiva. Ese valor extraordinario para el tráfico jurídico, contrasta, sin embargo, con la extrema fragilidad jurídica de esos instrumentos normativos. Porque la nulidad es, al menos en su planteamiento teórico estricto, como si nada de lo que se hubiera hecho existiera.

Es más, ya no sorprende, por lo cotidiano en lo que se ha convertido, que leamos noticias relativas a la anulación judicial de este o de aquel plan, por uno u otro motivo. En este contexto, abatir un plan se ha convertido en una especie de deporte donde la pieza siempre cae al final con relativa facilidad. La nulidad del planeamiento se ha trivializado, hasta el punto de que existen incluso algunos libros de autoayuda al estilo de cómo impugnar una multa de tráfico, con la finalidad de conseguir la anulación del plan; guías en las que se detalla la jurisprudencia sobre los diversos vicios que han sido apreciados, incluso con estadísticas sobre cuáles son las causas más valoradas con vistas a conseguir el efecto invalidante ${ }^{3}$. A esto hemos llegado.

Culminar un plan con éxito en esta coyuntura se ha convertido en una especie de misión imposible. La complejidad que ha alcanzado al planeamiento favorece esta situación: requerimientos jerárquicos, sustantivos, ambientales, procedimentales, formales cada vez más estrictos, son el caldo de cultivo ideal

1 Texto de la ponencia presentada al VI Seminario La reforma del Estado. El régimen de la invalidez en el ámbito del Derecho Administrativo, organizado por el INAP (10 de octubre de 2018), dirigido por los profesores Santiago MUÑOZ MACHADO y Mariano LÓPEZ BENÍTEZ. Sobre el tema objeto de este estudio he tenido la ocasión de pronunciarme en otros trabajos anteriores, cuyas ideas se siguen en algunos casos de forma más simplificada al objeto de no sobrecargar el texto y sin perjuicio de los nuevos desarrollos a raíz de la evolución doctrinal y normativa, GONZÁLEZ SANFIEL, A. (2011): "Invalidez sobrevenida de los actos de aplicación del planeamiento urbanístico nulo", en Estudios sobre planeamiento territorial y urbanístico, Valencia: Tirant lo Blanch, págs. 285-307; ídem (2016): "El principio de especialidad como límite a la declaración de nulidad del planeamiento", en El derecho de la ciudad y el territorio. Libro homenaje a Manuel Ballbé Prunés, BASSOLS COMA, M., MENÉNDEZ REXACH, Á., GIUFREU, J. (coords.), Madrid: INAP, págs. 911-924; ídem (2017): "Límites a la declaración de nulidad del planeamiento", en LÓPEZ RAMÓN, F., VILLAR ROJAS, F. J. (coords.), El alcance de la invalidez de la actuación administrativa, Actas del XII Congreso de la Asociación Española de Profesores de Derecho Administrativo, Madrid: AEPDA-INAP, págs. 411-459. El presente trabajo forma parte de la línea de investigación del proyecto de la Agencia Estatal de Investigación Nuevo Derecho urbanístico (DER2017-84387-P) del que el autor es el investigador principal.

${ }^{2}$ La gráfica expresión es usada por RENAU FAUBELL, F. (2016): "Nulidad radioactiva de los planes urbanísticos por defectos en el procedimiento de aprobación", en Noticias Jurídicas accesible en abierto.

3 Según G. GARCÍA MORILLO del análisis estadístico que realiza a partir de las sentencias analizadas, la mayor causa de nulidad es la que tiene que ver con la evaluación ambiental (41\%), le siguen los informes sectoriales (30\%) y, a continuación, las cuestiones relativas a exposición pública del plan (24\%), ORTEGA MORILLO, G. (2018): La nulidad del planeamiento general urbanístico. Guía práctica para anular un PGOU, Madrid: Sepin, pág. 111. 
para que al final del camino se eche por tierra tanto esfuerzo. No es un problema localizado geográficamente: el virus se extiende por todo el país. Los planes de grandes o medianas ciudades en todas las Comunidades autónomas se ven afectadas por aquellas declaraciones de nulidad, generando la consecuente incertidumbre e inseguridad, todo lo contrario a la finalidad que debe proporcionar el Derecho. Varios años para aprobar el plan, varios años para que recaiga la sentencia anulatoria, varios aún para que se recomponga la situación. Demasiado tiempo para lo que un sistema jurídico, económico y social puede soportar.

Otros países de nuestro entorno, que han pasado ya por estos mismos problemas, los han afrontado realizando cambios jurisprudenciales y normativos tendentes a reforzar la seguridad jurídica y a proteger los intereses que el planeamiento tutela, una senda que debería ser imitada, tal y como nos ha servido de ayuda en otras ocasiones.

La situación de incertidumbre e, incluso, puede decirse que hasta de desasosiego, ha provocado una reacción doctrinal que reclama un cambio de rumbo en relación con el tratamiento de la nulidad, tanto a nivel general como en el particular, sobre el ámbito del Derecho urbanístico. Muestra de ello fue el XII Congreso de la Asociación española de Profesores de Derecho Administrativo celebrado en la ciudad de La Laguna en febrero de 2017, que se dedicó monográficamente al tema de la nulidad, que refleja muy bien el status questionis, en una materia en la que no dejan de seguir apareciendo nuevas aportaciones, fruto de la importancia e interés que suscita la cuestión ${ }^{4}$.

Para poner freno a esta especie de estado general de anulación del planeamiento, hubo ya un intento de reforma legal auspiciado por el anterior Ministerio de Fomento, que se quedó en la mera presentación del anteproyecto ante la prensa. Esta reforma pretendía modificar determinados aspectos de la legislación estatal del suelo y de la jurisdicción contencioso-administrativa. No obstante, el cambio de Gobierno ha dejado en suspenso la reclamada reforma, puesto que parece ser que una rectificación interpretativa per se no sería suficiente para dar un giro a la situación. Aunque no se sepan cuáles van a ser las medidas concretas que pudieran adoptarse, de lo que no cabe duda es que, en algún momento, se deberá abordar la rectificación del modelo actual. Se podría decir aquí también aquello de certus an, incertus quando.

\section{RADIOGRAFÍA Y PATOLOGÍAS DE UN SISTEMA FORMALISTA A LA LUZ DE LA JURISPRUDENCIA}

A través de la jurisprudencia se han ido conociendo la gran cantidad de planes y actos administrativos de contenido urbanístico que han sido anulados en nuestro país. No existen estadísticas ni cifras ciertas, pero de ella se desprende sin grandes esfuerzos que es un problema general sin resolver. La idea central que domina todo es que los planes son normas de naturaleza reglamentaria y la sanción de nulidad, cualquiera que sea el vicio alegado, es siempre en grado máximo, es decir, nulidad absoluta o de pleno derecho. A este planteamiento se asocian toda una serie de consecuencias, que se irradian tanto sobre otros planes (los planes de desarrollo o derivados), como sobre los actos administrativos que han aplicado los planes anulados, que también estarían afectos por aquella nulidad; también sobre las posibilidades de actuación futuras una vez que aquella nulidad ha sido declarada judicialmente, de modo que no se entienda que las actuaciones adoptadas con posterioridad a dicho pronunciamiento judicial se hacen con la finalidad de defraudar o eludir el cumplimiento de la sentencia. Esta sería la idea elemental o básica de dicha construcción, pero existen una serie de singularidades que, de forma sintética cabe si quiera exponer, con la finalidad de tener una mejor comprensión del fenómeno.

\footnotetext{
${ }^{4}$ LÓPEZ RAMÓN, F., VILLAR ROJAS, F. J. (coord.) (2017): La invalidez..., op. cit.; GARCÍA LUENGO, J. (2017): Las infracciones formales como causa de invalidez del acto administrativo. Un estudio sobre el artículo 48.2 de la Ley 39/2015, lustel, que completa la gran aportación de este autor en materia de nulidad; SORIA MARTÍNEZ, G., BASSOLS COMA, M. (2017): Los efectos de la nulidad de los instrumentos de planeamiento urbanístico, Madrid: Thomson Reuters-Aranzadi, haciendo referencia también a los efectos registrales, civiles, fiscales o penales que puede provocar aquella; FERNÁNDEZ, T. R. (2017): "El contencioso urbanístico y su necesaria reforma", en Revista de Administración Pública, núm. 203, págs. 137-162, retomando otro trabajo anterior en el que, apoyándose en la experiencia francesa, aporta mucha luz sobre la forma de abordar el problema, alejado de dogmatismos; LÓPEZ RAMÓN, F. (2018): "La calificación de los vicios de los reglamentos", en Revista de Administración Pública, núm. 205, págs. 13-48, en la que el autor aboga por la posibilidad de utilizar también la técnica de la anulabilidad, justificando que la interpretación actual no deriva de una correcta lectura y evolución de su tratamiento; AGUDO GONZÁLEZ, J. (coord.) (2018): Nulidad de planeamiento y ejecución de sentencias, Barcelona: Bosch editor, que contiene varios trabajos muy actuales e interesantes, de los que se dará cuenta en su lugar.
} 
a) Los planes (urbanísticos o territoriales) son normas de naturaleza reglamentaria. Esto es una idea ampliamente asentada, legal, doctrinalmente y jurisprudencialmente ${ }^{5}$. La sanción de nulidad, en cuanto tales, es siempre en grado máximo, es decir, nulidad absoluta o de pleno derecho. Esa nulidad puede ponerse de manifiesto tanto en impugnación directa como indirecta, teniendo en cuenta, a su vez, la existencia de acción pública en materia urbanística, lo que abre más las posibilidades impugnatorias ${ }^{6}$.

b) En principio, cualquier vulneración de la normativa determinaría aquella sanción de nulidad. En unos casos puede ser la infracción de otros planes superiores (jerarquía normativa entre planes); en otro los defectos formales, entre los que ocupan un papel destacado la omisión de informes sectoriales de todo tipo, preceptivos y vinculantes; las exigencias de evaluación ambiental, la falta de motivación en la memoria, problemas con la participación pública, incluso, la falta de publicación de la normativa, entre otras. Lo importante es que cualquiera de los requerimientos que se esgriman, acarrearían aquella nulidad ${ }^{7}$.

c) Si la nulidad afecta a un plan superior, también quedan viciados de nulidad todos los planes de desarrollo o derivados que se han aprobado para partes más pequeñas. De esta manera, si se anula el planeamiento general, ineludiblemente ello afectará a los planes parciales, especiales o estudios de detalle que se hubieran aprobado.

d) Igualmente si los planes son anulados, todos los actos administrativos que lo hubieran aplicado pierden su correspondiente cobertura normativa y son, igualmente, nulos ${ }^{8}$. De este modo, si el plan parcial es anulado, también esa nulidad afectará al proyecto de urbanización, al instrumento de equidistribución (p. ej. reparcelación o proyecto de compensación), a la licencia de edificación o al correspondiente convenio urbanístico, por citar algunos actos urbanísticos característicos (nulidad en cascada o actos encadenados).

e) Asimismo, al anularse un plan no sería posible aplicar las técnicas de subsanación o convalidación (puesto que ello sólo se aplica a actos administrativos anulables) ${ }^{9}$. Igualmente, tampoco sería posible con-

${ }^{5}$ La naturaleza reglamentaria al inicio fue una cuestión controvertida. Curiosamente, hoy vuelve a revivirse cierta polémica en relación a este tema, al menos para reconsiderar que la totalidad del plan tenga aquel carácter. Dentro de las diferentes manifestaciones doctrinales defendieron la naturaleza reglamentaria, GARCÍA DE ENTERRÍA, E. y PAREJO ALFONSO, L. (1979): Lecciones de Derecho urbanístico. I, Madrid: Civitas, págs. 163-172, sin perjuicio de la matizaciones que los propios autores han expresado con posterioridad respecto de la singularidad del plan, tal y como se tendrá oportunidad de exponer en el correspondiente lugar; TRAYTER JIMÉNEZ, J. M. (1996): El control del planeamiento urbanístico, Madrid: Civitas, págs. 33-89; MUÑOZ MACHADO, S., LÓPEZ BENÍTEZ, M. (2009): El planeamiento urbanístico, Madrid: lustel, págs. 61-66; PARDO ÁLVAREZ, M. (2005): La potestad de planeamiento urbanístico bajo el Estado social, autonómico y democrático de Derecho, Madrid: Marcial Pons, págs. 293-329; MARTíN REBOLLO , L. (2009): "El planeamiento municipal: perspectiva general", en Fundamentos de Derecho urbanístico. I, Madrid: Aranzadi-Thomson Reuters, págs. 250-251. Sobre la evolución de la doctrina y jurisprudencia en esta materia, así como formulando propuestas de mejora del modelo, ha vuelto recientemente BASSOLS COMA, M. (2017): "La asimilación de los planes de urbanismo a normas reglamentarias y problemática jurídica de su anulación", en SORIA MARTíNEZ, Gabriel, BASSOLS COMA, Martín (coords.): Los efectos de la nulidad..., op. cit, 27-102. Todo ello sin perjuicio de aquellas propuestas actuales de reconsideración o restricción de la naturaleza reglamentaria del plan que se indican más adelante.

${ }^{6}$ Sobre la nulidad de las normas reglamentarias GARCÍA DE ENTERRÍA, E., FERNÁNDEZ, T. R. (2015): Curso de Derecho Administrativo, I, 17. ${ }^{a}$ ed., Madrid: Civitas-Thomson Reuter, págs. 247-261; DOMÉNECH PASCUAL, G. (2002): La invalidez de los reglamentos, Valencia: Tirant lo Blanch; FERNÁNDEZ SALMERÓN, M. (2002): El control jurisdiccional de los reglamentos. Procedimiento administrativo, proceso judicial y potestad reglamentaria, Barcelona: Atellier; MUÑOZ MACHADO, S. (2006): Tratado de Derecho Administrativo y Derecho público general. II, Madrid: lustel, págs. 1.147-1.168; 1.299-1.317; AGOUÉS MENDIZÁBAL, Carmen (2014): "Los efectos de las sentencias que declaran la nulidad de las disposiciones administrativas de carácter general", en Revista Vasca de Administración Pública, núm. especial 99-100 Homenaje a Demetrio Loperena y Ramón Martín Mateo, págs. 65-85; ídem, (2017): "La modulación de los efectos de la invalidez de los reglamentos", en LÓPEZ RAMÓN, Fernando, VILLAR ROJAS, Francisco J. (coords.): El alcance de la invalidez..., op. cit., págs. 361-410.

7 Una recopilación de los diversos vicios apreciados por la jurisprudencia en ORTEGA MORILLO, G. (2018): La nulidad del planeamiento..., op. cit., con cuadros estadísticos de la jurisprudencia analizada; igualmente, RAMOS MEDRANO, J. A. (2015): "Los 10 errores más básicos y frecuentes en el urbanismo español", en Actualidad jurídica ambiental, núm. 52; el mismo autor sobre otros vicios puntuales: (2017) "Más de 90 planes de urbanismo anulados judicialmente por no justificar la disponibilidad de evaluación ambiental", Actualidad jurídica ambiental, núm. 73; ídem (2017) "Más de 90 planes de urbanismo anulados judicialmente por no justificar la disponibilidad de recursos hídricos", en la misma revista, núm. 67, en ambos casos con anexos sobre las sentencias citadas. En relación con este último informe, también, SUAY RINCÓN, J. (2015): "Planeamiento urbanístico y recursos hídricos. Condicionantes formales y materiales", en Planificación y ordenamiento jurídico de los recursos hídricos, Colección Derecho de Aguas 4, Fundación Agbar-Consejo General del Poder Judicial, págs. 21-100.

8 GIFREU FONT, J. desarrolla, a la vista de la jurisprudencia, diversos supuestos de nulidad de los actos de aplicación cuando se anulan los planes que le sirven de cobertura (2017): "Los efectos jurídicos de la anulación del planeamiento urbanístico sobre los actos singulares de aplicación. Especial referencia a los instrumentos de ejecución y títulos administrativos habilitantes dictados a su amparo", en SORIA MARTÍNEZ, Gabriel, BASSOLS COMA, Martín (coords.): Los efectos de la nulidad..., op. cit., págs. 145-228.

9 Una muestra de la amplia jurisprudencia sobre este extremo, resaltando que no cabe la anulabilidad del reglamento y, en consecuencia, las técnicas de conservación de actos y trámites, entre otras, SSTS de 27 de noviembre de 2015 (roj: 4971/2015), 6 de mayo de 2015 (roj: 2037/2015), 2 de mayo de 2015 (roj: 2090/2015) o 18 de octubre de 2013 (roj: 5113/2013). Especialmente críticos con 
servar los actos o trámites que se hubieran realizado, puesto que según esa jurisprudencia dicha técnica sólo está prevista para los actos administrativos, pero no para los reglamentos, naturaleza que tienen los planes.

f) En el caso particular de la falta de publicación del plan, se ha diferenciado dos situaciones. De una parte, si dicha publicidad afecta al instrumento general (por ejemplo el plan general de ordenación), ello determina la ineficacia del plan y no su nulidad. De otra parte, están aquellos planes de desarrollo o derivados que han sido aprobados sobre la base de un planeamiento general no publicado. En este último supuesto, los mismos serían nulos de pleno derecho por infracción del principio de jerarquía normativa ${ }^{10}$.

g) Cuando se anula el plan se produce la reviviscencia del planeamiento anterior al anulado. Es decir, la cláusula derogatoria del plan anulado no desplegaría efectos, volviendo a recuperar su vigencia el planeamiento precedente ${ }^{11}$.

h) Existen especiales cautelas para evitar que las medidas adoptadas con posterioridad a la sentencia anulatoria del plan, impliquen un falseamiento o incumplimiento del fallo, lo que determinaría la nulidad absoluta de dicha actuación por aplicación del artículo 103.4 LJ. Ello impide que exista un especial deber de motivación cuando se aprueba un planeamiento posterior para justificar que su función no es exclusivamente legalizar o convalidar lo declarado nulo, exigiéndose que la modificación del planeamiento tenga una cobertura más amplia o responde a otros intereses públicos diferentes a los exclusivos del plan anulado ${ }^{12}$.

No obstante esta configuración, también de la jurisprudencia utiliza dos importantes límites a la declaración de nulidad:

- Se admite que si es posible encontrar otro fundamento jurídico después de la nulidad ( $p$. ej. otro plan o una normativa que dé cobertura a tales actos), se considerarán válidos los planes o actos aplicados. La nulidad no les afectará, puesto que pueden justificar su existencia en otro fundamento ${ }^{13}$.

- Se protegen los actos firmes que se hubieran consolidado con anterioridad a la declaración de la sentencia anulatoria del plan, por aplicación del artículo 73 LJ (antes art. 120 LPA). Es decir, que la nulidad del planeamiento no implica o acarrea por sí misma la de los actos urbanísticos firmes que la hubieran aplicado antes de aquella declaración de nulidad. Sobre este límite se volverá más adelante.

A raíz de la doctrina expuesta, más allá de algún matiz puntual en algún caso concreto, los Tribunales vienen anulando los planes urbanísticos y territoriales, así como los actos administrativos que lo han apli-

este planteamiento, rechazándolo, SANTAMARÍA PASTOR, J. A. (2014): "Muerte y transfiguración de las desviación de poder: sobre las sentencias anulatorias de planes urbanísticos", en Revista de Administración Pública, núm. 195, pág. 215 y FERNÁNDEZ, T. R. (2017): op. cit., págs. 153-154, en relación con el plan general de Madrid.

10 Por todas, STS de 16 de noviembre de 2009 (roj: 7061/2009).

11 Explicó este efecto, por ejemplo, TORNOS MÁS, J. al hilo del comentario de una sentencia que anuló un Decreto legislativo: «Dicha nulidad afecta también a la derogación contenida en esta norma y, en consecuencia, renace el texto derogado, ya que en verdad no fue derogado, no perdió nunca su vigencia. Y ello es lógico y coherente con el argumento anterior: como la nulidad no aporta nada nuevo, a diferencia de la derogación, debe renacer el texto anterior al desaparecer el que dispuso su derogación» (1982), "De nuevo sobre el control de los Decretos legislativos: la declaración de nulidad, por vicios de carácter procedimental, del Decreto de 20 de diciembre de 1974, en materia de disciplina de mercado", en Revista Española de Derecho Administrativo, núm. 32, pág. 894, de ahí que Ios actos puedan encontrar cobertura en la norma derogada; también sobre el tema DOMÉNECH PASCUAL, G. (2002): La invalidez..., op. cit., pág. 292 y ss. En el Derecho francés se ha limitado este efecto cuando se acredite motivadamente que han existido cambios de hecho y de derecho, se entiende que por el efecto contradictorio que produce, lo que permite la aplicación directa de las disposiciones del Código del urbanismo (SAVARIT-BOURGEOIS, I. (2014): Droit de l'Urbanisme, Gualiano, pág. 281). Es decir que entre aplicar una normativa totalmente desfasada se opta por aplicar directamente el marco legal y no el plan derogado que recobra su vigencia. De este modo se evitan las antinomias realidad-plan derogado. Un resumen de su aplicación en el Derecho francés, con respaldo normativo expreso, en AUBY, J. B., PÉRINET-MARQUET, H., NOGUELLOU, R. (2012): Droit de l'urbanisme et de la construction, 9. ${ }^{a}$ ed., Paris: Montcherestien, págs. 147-150.

${ }^{12}$ Existe una amplia bibliografía sobre el tema de la ejecución de sentencias, para el ámbito urbanístico pueden destacarse GEIS I CARRERAS, Gemma (2013): La ejecución de las sentencias urbanísticas, 2. ${ }^{a}$ ed., Barcelona: Atellier; y recientemente, AGUDO GONZÁLEZ, J. (coords.), op. cit.

13 Así lo recoge la jurisprudencia, tal y como lo expresan, por ejemplo, las SSTS de 15 de junio de 1987 (RJ 1987/6126); 25 de marzo de 1991 (RJ 1991/2018); 12 de julio de 1991 (RJ 5594); 20 de diciembre de 1994 (RJ 1994/10705); 31 de marzo de 2003 (RJ 2003/2868). La idea había sido propuesta doctrinalmente por GÓMEZ-FERRER MORANT, R. que señalaba que frente a la anulación de la disposición de carácter general «habrá que precisar si estos actos incurren en un vicio determinante de nulidad o de anulabilidad o, incluso si son plenamente válidos» (1977): "Nulidad de Reglamentos y actos dictados durante su vigencia", en Revista Española de Derecho Administrativo, núm. 14, pág. 398 y es defendida también por BELADÍEZ ROJO, M. (1994): Validez y eficacia de los actos administrativos, Madrid: Marcial Pons, pág. 334; o CANO CAMPOS, T. (2004), La invalidez sobrevenida de los actos administrativos, Madrid: Thomson-Civitas, pág. 272. 
DA. Nueva Época - N. ${ }^{\circ}$ 5, enero-diciembre 2018 - ISSN: 1989-8983 - DOI: 10.24965/da.v0i5.10607 - [Págs. 46-68]

Nulidad del planeamiento urbanístico e invalidez de los actos amparados en el mismo. Atención especial a las nuevas..

Andrés M. González Sanfiel (España)

cado. La excepción es que encuentren otra cobertura en el ordenamiento jurídico en un sentido amplio, así como la protección de los actos firmes que sobreviven a aquella anulación.

\section{LA SENDA DE FLEXIBILIZACIÓN EMPRENDIDA POR OTROS PAISES}

La anulación de los planes como problema que afecta a la seguridad del tráfico jurídico, no es exclusivo de nuestro país. Otros sistemas que nos han servido de modelo en otras ocasiones, como Alemania, Francia o Italia, también han tenido que afrontarlo, aportando soluciones tendentes a proporcionar una mayor certidumbre jurídica en el planeamiento frente a las posibles impugnaciones ${ }^{14}$. En términos generales, puede decirse que las soluciones aportadas por el Derecho comparado restringen las posibilidades de declarar la nulidad. Ello se ha realizado incorporando diversas medidas, algunas de ellas aportaciones jurisprudenciales, otras han venido de cambios normativos. En esencia, tales modificaciones se basan en una serie de ideas, tales como la preservación del plan por la seguridad que aporta, la restricción de los motivos de impugnación, la reducción de plazos impugnatorios, la posibilidad de subsanación de defectos o el apoderamiento al juez para que supervise el proceso de reconstrucción del plan en vía judicial, otorgando un plazo adecuado a la Administración para que afronte esta tarea, con una posición más activa; todo ello con las correspondientes singularidades y modos en los que cada uno de esos sistema han consolidado tales situaciones. En cualquier caso, la situación es muy diferente a la española, puesto que tales sistemas tienden a conservar y proteger los planes impugnados. Ello ha pasado por flexibilizar el tratamiento impugnatorio de los requisitos formales exigidos a los planes, salvo algunas excepciones expresamente recogidas en la normativa.

La doctrina española conoce y ha dado cuenta de las diferentes soluciones que podrían servirnos de inspiración, al menos en la idea fundamental: el plan tiene unos valores que, incluso aunque tenga vicios formales, deben ser objeto de protección tomando las medidas necesarias para subsanarlos y corregir los defectos de que adolezcan, todo incluso en sede judicial. En muchos casos, los cambios no veían motivados porque se tratara de una cuestión cuantitativa, sino porque se consideraba necesario reforzar la seguridad jurídica, viendo la nulidad como algo insostenible para un sistema jurídico-económico.

En el caso de Alemania el sistema consagró tempranamente el denominado principio de conservación de los planes urbanísticos (DOMÉNECH PASCUAL), que protege la seguridad jurídica otorgada por el mismo frente a los vicios de forma, procedimentales o de ponderación (contenido) que aquellos planes puedan contener ${ }^{15}$. PAREJO ALFONSO ha realizado una síntesis de las consecuencias que derivan de este principio ${ }^{16}$. Por lo que aquí importa, lo relevante en el caso de vicios de procedimiento o formales, así como en los relativos a la ponderación, es determinar en qué medida han tenido aquellos una influencia determinante en el resultado del procedimiento o de la ponderación (es decir, una perspectiva sustantiva). En cualquier caso, es posible llevar a cabo la subsanación de las infracciones, incluso con carácter retroactivo. Además, si transcurre un año desde la publicación del plan, cualquier vicio resulta irrelevante a efectos invalidantes.

En una línea similar se expresa el Derecho francés, de cuya evolución ha dado muy buena cuenta T. R. FERNÁNDEZ, que realiza una valoración muy favorable de los cambios introducidos en el país vecino ${ }^{17}$. A

14 Sin perjuicio de otras referencias concretas, una valoración global de algunas reformas en BASSOLS COMA, M. (2007): "Panorama del Derecho urbanístico comparado", en Serie Claves del Gobierno Local, núm. 5, Fundación Democracia y Gobierno Local, págs. 11-25; ídem (2017), op. cit., págs. 86-91, con referencias al Derecho alemán y francés.

15 En esencia en los artículos 214 y 215 del Código de urbanismo. DOMÉNECH PASCUAL, G. (2002), op. cit., págs. 140-178. Se hace eco de este planteamiento MUÑOZ MACHADO, S. (2006): op. cit., págs. 1.158-1.167. Una visión global sobre el Derecho urbanístico alemán en RODRÍGUEZ DE SANTIAGO, J. M. ${ }^{a}$ (1998): "Líneas básicas de la legislación urbanística de la República Federal de Alemania", en Revista de Derecho urbanístico y medioambiente, núm. 163, págs. 29-62; PAREJO ALFONSO, L. (2013): "La ordenación urbanística en Alemania", Parte I y parte II, en la Revista de Derecho urbanístico y medioambiente, números 281 (págs. 13-82) y 282 (págs. 13-77), respectivamente; ídem (2017): "El plan urbanístico no es solo norma. En pro de la superación de la doctrina simplificadora de su naturaleza”, en Práctica urbanística, núm. 141, págs. 9-13, en las que simplifica el modelo alemán en relación con el principio de conservación de planes. También, sobre la relativización de los requisitos o vicios formales, SCHMIDT-ABMANN, Eberhard (2011): «L'illegittiità degli atti amministrativi per vizi di forma del procedimento e la tutela del cittadino», en Diritto Amministrativo, núm. 3, págs. 471-497.

16 PAREJO ALFONSO, L. (2013): Parte II, op. cit., págs. 75-77.

17 FERNÁNDEZ, T. R. (2013): "Proceso contencioso-administrativo: semejanzas y diferencias de los casos francés y español", en Revista de Urbanismo y Edificación, núm. 29, págs. 77-95 y (2017): op. cit., págs. 137-162. En este segundo artículo, al hilo de las novedades del sistema francés, el prestigioso profesor realiza una crítica demoledora de la aplicación de la doctrina de la nulidad absoluta que hace la jurisprudencia de nuestro país en relación con el planeamiento. Su lectura es altamente recomendable para comprender la diferencia entre la teoría de la nulidad y lo que debe ser su aplicación, sin que ello suponga una desvalorización 
través de sucesivas reformas en las normas del contencioso-urbanístico, los aspectos a destacar afectan, entre otros $\mathrm{a}^{18}$ : a) relativización de los vicios formales o de procedimiento; b) ampliación de los poderes del juez; c) posibilidad de subsanación de los vicios, incluso en vía judicial otorgándose un plazo a la Administración para ello; d) limitación temporal y restricciones de legitimación para recurrir el planeamiento; e) posibilidad de acotar la nulidad a ciertas partes cuando el vicio afecte notablemente a un plan.

Otro dato importante de esta evolución, incluso previa a dichos cambios legales, ha venido de la mano de la jurisprudencia del Consejo de Estado francés, rompiendo la idea clásica de que la nulidad del reglamento (plan) acarrea ineludiblemente la nulidad de los actos administrativos que lo han aplicado (p. ej. el permiso para construir) ${ }^{19}$. El conocido como dictamen GREPO de 12 de diciembre de 1986 (núm. 54.701) dispuso que las autorizaciones de urbanismo no constituyen medidas de aplicación del plan considerado, de suerte que la autorización es autónoma en su relación con el plan. De este modo, el citado Consejo abandona el criterio del carácter indisociable entre plan y acto administrativo (confirmado en el Dictamen de 7 de febrero de 2008). Con ello, se afirma que ya no es posible solicitar la nulidad de un permiso de construcción basándose únicamente en que el plan que lo aplicó es ilegal ${ }^{20}$. Todo este planteamiento difiere sustancialmente de la denominada nulidad en cascada o encadenada que se puede leer en alguna sentencia en nuestro país. Además, este proceso de adaptación del Derecho francés, en orden a garantizar una mayor seguridad jurídica, continúa en la actualidad, con nuevos grupos de trabajos específicos para incorporar los cambios necesarios en el contencioso del urbanismo. Todo ello con vistas a seguir reforzando la seguridad jurídica de los planes y actos administrativos en el ámbito del urbanismo. El proceso sigue abierto y en permanente ajuste, a la vista de las iniciativas que se siguen sucediendo ${ }^{21}$.

de la misma, sino su correcta aplicación teniendo en cuenta otros factores jurídicos que amortiguan sus efectos, en la línea con lo que se defiende. También, FERNÁNDEZ TORRES, J. R. (2013): "Renovación del derecho urbanístico en Francia y obligación de apertura de una proceso de debate y reflexión en España", en Revista de Urbanismo y Edificación, núm. 29, págs. 9-11. Un planteamiento de conjunto sobre el Derecho urbanístico francés, también en PAREJO ALFONSO, L. (2015): "Derecho urbanístico francés, Parte I y Parte II", en Revista de Derecho urbanístico y medioambiente, números 301 (págs. 17-76) y 302 (págs. 17-69), respectivamente.

18 En esencia en los artículos L600-1 a L600-13 del Código de urbanismo, disposiciones relativas al contencioso del urbanismo. Debe señalarse que el proceso de cambio del contencioso del urbanismo francés no ha parado en las últimas décadas. Cada reforma introducida en el mismo se ha basado en un comité de trabajo previo con amplia participación, a raíz de los cuales se han adoptado las medidas necesarias para introducir los cambios oportunos al objeto de reforzar la seguridad jurídica. Se entiende que ese proceso se inicia con la Ley núm. 94-122 de 9 de febrero sobre diversas disposiciones en materia de urbanismo y construcción (conocida como Ley Bosson). Esta Ley se tomó sobre la base de las propuestas formuladas por el Consejo de Estado francés en su informe El urbanismo: por un derecho más eficaz del año 1992. Dicha Ley otorgó una mayor seguridad a los documentos de los planes y limita las consecuencias de su ilegalidad sobre los permisos individuales de construir. Continuó con la Ley núm. 2000/1208 de 13 de diciembre sobre solidaridad y renovación urbana (Ley SRU). Esta Ley derogó el principio de «economía de los motivos» obligando al juez a pronunciarse sobre el conjunto de los motivos alegados, de modo que se eviten en relación con una misma solicitud nuevos recursos judiciales (frente al planteamiento de que se estime un motivo impugnatorio y no se entra al fondo del resto). En 2006 se aprobó la ley núm. 2006/872 de 13 de julio sobre Compromiso Nacional para la Vivienda (Ley ENL), que restringe el derecho de acción de las asociaciones y permite al juez anular parcialmente un permiso de construir. En esta ocasión las reformas se adoptaron sobre la base del Informe Proposición para una mejor seguridad jurídica de las autorizaciones de urbanismo, presentado por el grupo de trabajo presidido por Philippe PELLETIER (enero de 2015).

El proceso de cambio continúa con las reformas del año 2013 y siguientes, de lo que da cuenta T. R. FERNÁNDEZ. En esta ocasión, la base de las reformas están en el Informe Labetoulle de 2013 (Construcción y derecho a los recursos: por un mejor equilibrio) que cuajó en las reformas legales de la Ordenanza 2013/638, de 18 de julio, completada con el Decreto 2013/879. Así como la Ley denominada ALUR, de 24 de marzo de 2014, para el acceso a la vivienda y un urbanismo renovado y la Ley 2015/990, de 6 de agosto, para el crecimiento, la actividad y la igualdad de las oportunidades económicas (conocida como Ley Macron). Se completa esta evolución, hasta el momento, con la Ley núm. $2017 / 86$ de 27 de enero relativa a la Igualdad y la Ciudadanía que introduce un principio de caducidad en las reclamaciones cuando no se aporten en 3 meses los documentos necesarios para juzgar el caso (p. ej. estatutos de la asociación reclamente, título de propiedad de un vecino, etc.).

Una evolución sobre las disposiciones del contencioso del urbanismo francés en BOUYA, D. (2017): Le plan local d'urbanisme à l'épreuve de la hiérarchie des normes, These de doctorat de L'Université de Lyon, págs. 319 y ss., accesible en abierto. También, el Estudio de la Agencia de Urbanismo AURAV, Les contentieux de l'urbanisme: un frein à la production de logements?, abril de 2017, especialmente págs. 12-16.

19 Así lo expone SAVARIT-BOURGEOIS, I. (2014), op. cit, págs. 279-280.

20 Ibidem.

${ }_{21}$ Así lo atestigua, por ejemplo, la Proposición para un contencioso de las autorizaciones del urbanismo más rápido y eficaz, realizada por el grupo de trabajo presidida por la Consejera de Estado Christine MAUGÜÉ, por encargo de agosto de 2017 del Ministro de Cohesión territorial. Las propuestas de modificación del Código del urbanismo se centran en cuatro direcciones: a) la reducción en el retraso de los recursos en materia urbanística; b) la consolidación de las autorizaciones existentes; c) incremento de la seguridad jurídica de las construcciones terminadas; d) la mejora de las sanciones contra los recursos abusivos. También, el proyecto de Ley sobre evolución de la vivienda, el desarrollo y el digital que, previsiblemente, se apruebe este mismo año, y que al hilo de la promoción 
En Italia la flexibilidad del sistema no se ha producido de igual forma a lo acaecido en Alemania o Francia. No existe una reforma de la legislación urbanística en la que fundar ese cambio. Lo que sí puede encontrarse son elementos que han ido incorporándose en la legislación administrativa general tendentes a reforzar la seguridad jurídica, por influencia alemana sobre la doctrina del resultado y relativización de los vicios formales ${ }^{22}$. Es previsible que estos cambios se proyecten sobre el ámbito urbanístico, lo que se suma a elementos flexibles que existen en el propio Derecho urbanístico. El resultado, en cualquier caso, es que existen elementos que caminan en la misma dirección de relativizar los vicios formales o procedimentales, de limitar la impugnación para proteger la seguridad jurídica y de ampliar los poderes del juez contencioso, incluso en este último caso sin que se haya realizado una modificación de su legislación procesal, sino como algo consustancial a la tutela judicial que debe proporcionarse.

Un ejemplo de lo que se desea resaltar es la conocida como excepción de área urbanizada: si se establece en un plan superior la necesidad de aprobar un plan de desarrollo y se aprecia que la zona ya se encuentra urbanizada, aunque no se hubiera aprobado aquel plan de desarrollo, el propietario tiene derecho a que se le conceda la licencia. Ello sin necesidad de exigir la aprobación de aquel plan previo, cuya previsión se tiene por no puesta. En este supuesto, se reconoce la fuerza fáctica de la situación y, como ya está urbanizado, la licencia es posible obtenerla ${ }^{23}$. En nuestro país, la licencia sería nula porque el plan superior ordena que exista un plan de desarrollo (cuestión formal), aunque este no haga falta porque ya la zona está urbanizada.

La reforma de la legislación administrativa, recoge la idea de la importancia del vicio respecto del resultado final, de modo que, si la decisión final no cambia no se invalida la actuación, planteamiento del que el urbanismo no está excluido. Es decir, el Derecho urbanístico, los planes y actos administrativos que se desenvuelven en él, no están exentos de la evolución general que atraviesa la legislación administrativa italiana.

En definitiva, la legislación de algunos países que nos han servido de inspiración o modelo para constatar otras soluciones jurídicas que se alejan de concepciones formalistas en general sobre los vicios procedimentales o formales. Ello tiene una clara repercusión sobre el urbanismo, limitando las consecuencias anulatorias de los planes y protegiendo tanto el propio plan como los actos administrativos que lo aplican. Todo ello con las excepciones o matizaciones que correspondan, pero lo que no existe es una tendencia general a la anulación de los planes o de los actos urbanísticos cuando aquellos planes son anulados. Esa vía parece haberse cerrado en aras a la protección de los valores e intereses presentes en la planificación y la necesaria tutela de los derechos de los ciudadanos y promotores respecto de los actos administrativos que hayan aplicado aquellos planes, pese a las deficiencias formales o procedimentales en las que pudieran incurrir los mismos.

\section{LOS ACTOS FIRMES NO SE TOCAN. LÍMITES A LA REVISIÓN DE OFICIO}

Frente a la diversidad de mecanismos existentes en el Derecho comparado para frenar los efectos de la nulidad de los planes, en nuestro país uno de los pocos límites reconocidos es el de respetar los actos firmes, según quedó apuntado. Es un principio o regla general consagrada por la legislación procesal y que ha sido aplicado ampliamente. Lo recoge el conocido artículo 73 LJ (anterior 120 LPA) al disponer que «las sentencias firmes que anulen un precepto de una disposición general no afectarán por sí mismas a la eficacia de las sentencias o actos administrativos firmes que lo hayan aplicado antes de que la anulación alcanzara efectos generales, salvo en el caso de que la anulación del precepto supusiera la exclusión o la reducción de las sanciones aún no ejecutadas completamente».

Gracias a este amortiguador se han podido contener los efectos anulatorios de los planes en relación con los múltiples actos administrativos que lo han aplicado a lo largo de su vigencia. En principio, la nulidad del

\footnotetext{
y desarrollo de la vivienda, introduce diversas medidas de simplificación y refortalecimiento de la seguridad jurídica en el ámbito urbanístico, según los objetivos ya señalados.

22 Cuenta este fenómeno BUONFINO, Alberto (2014): "La disciplina della nullità provvedimentale nel sistema amministrativo tedesco: spunti per un'analisi di Diritto comparato", en Diritto Amministrativo, núm. 4, págs. 777-805; en la misma línea, LACAVA, Filippo (2015): Principio di legalità dell'azione amminis-trativa ed esigenze di risultato, Roma: Aracne Editrice, 456 págs., en la que se desarrolla la idea de la importancia de la consecución del resultado frente a posibles infracciones o vicios formales.

23 Dan cuenta de esta excepción, MENGOLI, Gian Carlo (2014): Manuale di Diritto urbanistico, 7. ${ }^{a}$ ed., Milano: Giuffrè Editore, pág. 207; GIOVAGNOLI, Roberto, MORELI, Sabrina (2014): Urbanistica e governo del territorio. Normativa e giurisprudenza ragionata, Milano: Giuffrè Editore, pág. 122.
} 
plan se proyecta sobre todos los actos que lo han aplicado, de manera que se podría justificar la nulidad del acto de aplicación (la licencia por ejemplo) en razón de que la norma (el plan) en el que sustentaba ya no existe en términos jurídicos por efecto de la nulidad absoluta. Ciertamente, este límite que protege la seguridad jurídica y modula los efectos de la declaración de nulidad del plan (reglamento) sobre los actos aplicativos, tiene un factor o elemento un tanto aleatorio, dependiendo de si ha sido impugnado o no el acto. De modo que, sobre la base de el mismo plan anulado y por razón de si fueron o no impugnados, unos actos pudieran ser anulados y desaparecer -los que fueron recurridos en plazo- y otros se conservarán, a pesar de quedar en principios viciados también con aquella nulidad. Sin embargo, la jurisprudencia, en este caso, ha valorado más la importancia de expulsar la norma ilegal del ordenamiento, que su afección concreta sobre los actos administrativos que la hubieran aplicado (por ejemplo, STS de 17 de junio de 2009, Roj: 5036/2009) ${ }^{24}$.

A título de ejemplo, podría recordarse que si se anulara un plan parcial y se hubieran aprobado todos los actos de ejecución del mismo, como la aprobación de los estatutos o bases de actuación de un sistema de compensación, el proyecto de urbanización o el proyecto de compensación, aquella nulidad no se proyecta automáticamente sobre tales actos que, de no haber sido impugnados y devenidos firmes, seguirían desplegando sus efectos a pesar de la nulidad del plan que da cobertura a tales actuaciones ${ }^{25}$. La jurisprudencia puede ofrecernos otros tantos casos singulares en los que se aprecia dicho límite, pero la idea en cualquier caso es que se protege el acto firme a pesar de la nulidad del plan que le da cobertura.

Frente a esta situación, otra cuestión que surge es si fuera posible instar una revisión de oficio de tal acto. A pesar de que técnicamente se pudiera iniciar tal procedimiento (art. 106.1 LPC), en realidad esta vía presenta innumerables obstáculos tanto legales, en cuanto a la existencia de la multiplicidad de límites que concurren en el ejercicio de las facultades revisoras (prescripción de acciones, confianza legítima, el tiempo transcurrido, etc.), tal y como recoge el artículo 110 LPC ${ }^{26}$. También cabe apelar al sentido común, es decir, ¡cómo se va a revisar de oficio los actos administrativos dictados en el ámbito territorial de todo un plan parcial, no digamos si se trata de un plan general! Sería algo verdaderamente irreal.

La técnica de la revisión de oficio no está pensada para dejar sin efecto la pluralidad de actos en masa que se han producido durante la vigencia de un plan anulado, ni tampoco aporta una solución al problema de partida: aquellos actos se dictaron sobre la base de una norma aprobada por la Administración que posteriormente fue anulada.

En relación con esta cuestión, posiblemente habría que incorporar, tal y como han utilizado otros sistemas, un plazo máximo para instar la revisión de oficio frente a la imprescriptibilidad actual, al objeto de superar la incertidumbre que plantea también la cláusula "el tiempo transcurrido», todo ello a pesar de las modulaciones que la jurisprudencia ha incorporado en relación con ese límite. Sería más oportuno, por razones de seguridad jurídica, cerrar y concretar un plazo determinado, a tener que en cada caso que interpretar si se dan o no las condiciones de la Ley.

Complementariamente, una parte de la doctrina defiende la independencia tanto de los planes de desarrollo, como de los actos que lo aplican, respecto del plan superior anulado. De esta manera, aunque se anulara un plan general, por ejemplo, ello no debería acarrear la nulidad de los planes parciales o de las licencias, equidistribución o proyectos de urbanización que lo han aplicado. Es una solución similar a la propugnada por el Consejo de Estado francés al romper a la idea del carácter indisociable de los planes inferiores respecto de los planes superiores o de los actos en relación con los planes. De tal modo que, en este caso, se consideren como actos independientes al objeto de quedar protegidos frente a la declaración de nulidad del plan. En este caso, la denominada reforma Madia en Italia, ha ido en la línea de cerrar las amplias vías revisoras de la Administración. Para que prospere una revisión no basta apelar genéricamente al incumplimiento de la legalidad, sino que, además, debe existir un interés público, concreto y actual. Ello debe llevar a la Administración a realizar un juicio valorativo entre la utilidad de declarar la ilegalidad o la de mantener el acto pese a la existencia de un vicio. Asimismo, se limita temporalmente la acción al plazo

${ }^{24}$ Cabe recordar la explicación que ofrece M. REBOLLO PUIG (1998) al señalar que «nada justifica que ello entrañe automática y necesariamente la anulación o ineficacia de ningún acto o sentencia ni, menos aún, que ello pudiera conseguirse en fase de ejecución de sentencia que anuló el reglamento», en "Artículo 73", en REDA núm. 100, pág. 533.

${ }_{25}$ El ejemplo concreto analizado en las SSTS de 2 de junio de 2016 (RJ 2016/3123) y 19 de junio de 2013 (RJ 2013/5629). En la primera sentencia se pretendía, en la ejecución de la sentencia, extender los efectos de la sentencia anulatoria del plan sobre todos los actos que lo aplicaban que no fueron impugnados y devinieron firmes.

${ }^{26}$ Dentro de la bibliografía existente, una exposición de la aplicación jurisprudencial de esta técnica en CORDÓN MORENO, F. (2013): La revisión de oficio de los actos administrativos y disposiciones de carácter general y su control jurisdiccional. Un estudio desde la jurisprudencia, Madrid: Civitas-Thomson Reuters. 
de dieciocho meses desde que se hubiera dictado el acto. Todo ello contrasta con la amplitud del plazo en nuestro sistema y la casuística de aplicar los límites a la revisión que pudieran concurrir. Se refuerza la seguridad jurídica, permitiendo un tiempo de reacción razonable, y no que quede la espada de Damocles indefinidamente sobre la ciudadanía ${ }^{27}$.

En definitiva, el acto firme debe seguir siendo un límite a la extensión de los efectos de la declaración de nulidad del plan. Sin embargo, en caso de una reforma normativa deberían cerrarse con mayor claridad las posibilidades de acudir a la revisión de oficio, tanto en su consideración como actos independientes, como limitando el plazo para instar la citada revisión ${ }^{28}$.

Junto a este límite es posible encontrar en nuestro sistema jurídico otros que podrían poner freno a los efectos anulatorios. Para ello es necesario realizar una interpretación de otros elementos que pueden extraerse de nuestro ordenamiento jurídico, pero cuya virtualidad no se ha extendido para limitar los efectos de la nulidad, aunque existan razones para ello. Son ideas, principios o referencias normativas que, pensadas para otras finalidades, no obstante, pueden ser utilizadas para limitar los efectos anulatorios de los planes. A ello se dedican los siguientes apartados.

\section{CAMBIAR EL MODELO JERÁRQUICO Y ENTRELAZADO DE PLANES Y DE ACTOS RESPECTO DE LOS PLANES}

El sistema de planeamiento se ha caracterizado por conformar una estructura jerárquica en la cual los planes inferiores se supeditan a los planes superiores. La infracción de los planes superiores determina la nulidad (jerarquía normativa entre planes). Pero, a su vez, este esquema genera, como sabemos, otras consecuencias: si cae el plan superior, el resto de planes que desarrollan o derivan de los anteriores, también son nulos al haber perdido la correspondiente cobertura normativa. Así lo ha explicado la jurisprudencia. Además, si el plan es anulado ello, en principio, también afecta a los actos que lo han aplicado, que no pueden existir: han perdido su cobertura normativa. Si cae el plan, caen los planes vinculados al mismo y todos los actos que lo hayan aplicado.

La jerarquía introduce numerosos motivos anulatorios, porque en la concepción del modelo todos están encadenados, entrelazados o dependientes unos de otros. Para reconducir la situación es fundamental romper con esta idea. Las críticas al sistema jerárquico y a la dependencia entre los diferentes planes no son nuevas; aunque ahora, posiblemente son más evidentes las disfunciones y anomalías que produce. Pero, ya lo ponía de manifiesto con clarividencia E. GARCÍA DE ENTERRÍA en el año 1998 al afirmar:

«podría aprovecharse para imaginar un sistema de planificación menos rígido y absorbente que aún luce en la Ley del Suelo de 1976, que manifiesta en una cadena jerárquica de planes completamente rigurosa...jhasta cinco escalones, cada uno vinculado estrictamente a los precedentes y ordenados a su sola ejecución! El mito de un plan omnicomprensivo y agotador, de duración prolongada en el tiempo, además, está en quiebra rigurosa en todo el pensamiento social europeo; no hay razón para mantenerlo incólume en el único campo del urbanismo, donde produce rigideces, largos y onerosos procesos de ejecución, grave coste social, en definitiva. Acaso conviene pensar en la posibilidad de una ruptura de esa malla jerárquica, facilitando proceso de modificación o adaptación más flexibles» ${ }^{29}$.

Si esa «malla jerárquica» introduce tal nivel de distorsión y favorece la nulidad artificial de tantos planes y actos administrativos urbanísticos (por su conexión con el plan superior cuya nulidad priva de cobertura

${ }_{27}$ Sobre esta importante reforma, TESSARO, T., PIOVESAN, S. (2015): La riforma Madia del procedimento amministrativo. La legge 241/90 dopo la legge 124/2015, Santarcangelo di Romagna: Maggioli Editore.

${ }^{28}$ En este sentido las críticas a la imprescriptibilidad sostenidas por SANTAMARÍA PASTOR, J. A. (2016): "El «nuevo» régimen de la revisión de oficio y de los recursos administrativos", en RVAP núm. 105, págs. 268-269.

29 GARCÍA DE ENTERRÍA, E. (1998): "El Derecho urbanístico español a la vista del siglo XXI", en Revista Española de Derecho Administrativo, núm. 99, págs. 399. En esta misma línea SANTAMARÍA PASTOR ha escrito que «habría que preguntarse si dicha complejidad no se debe a la ambición faraónica que es intrínseca a los planes urbanísticos. La noción de plan aún vigente en España es producto de la mentalidad hiperracionalista rampante en la primera mitad del siglo XIX, que creía posible regular toda la dinámica inmobiliaria y de servicios de cualquier tipo de asentamiento urbano: una fantasía que la dura realidad cada día desmonta anticipadamente», SANTAMARÍA PASTOR, J. A. (2014): op. cit., pág. 211. También, esta crítica al principio de jerarquía entre los planes en Italia, STELLA RICHTER, P. (2016): Diritto urbanistico, 4. ${ }^{a}$ ed., Milano: Giuffrè Editore, págs. 12-13, que recoge ideas previas. 
al resto), ese extremo es en donde deben incorporarse medidas que corrijan los excesos anulatorios por extensión (actos encadenados o normas encadenadas, podría añadirse). Lo cierto es que ya existen algunos ejemplos normativos que inciden en esta cuestión, desligándose de la relación de jerarquía. No se trata de un modelo cerrado o perfecto, pero cuenta con los suficientes datos que nos permiten constatar una tendencia de superación de dicho modelo tradicional. Algunas de esas manifestaciones, sin ánimo exhaustivo, se exponen a continuación.

a) Generalización de los supuestos de relaciones de competencia entre planes, sin vinculación formal al instrumento superior (autonomía funcional): el ejemplo más conocido sobre el particular nos lo proporcionó la LPHE de 1985. En esta Ley el plan especial no es una manifestación jerárquica del plan general, no actúa como un «desarrollo» del mismo. Es más, se puede aprobar incluso aunque aquel planeamiento general no exista: «la obligatoriedad de dicho Plan no podrá excusarse en la preexistencia de otro planeamiento contradictorio con la protección, ni en la inexistencia previa del planeamiento general» (señala el artículo $20.1 \mathrm{LPHE})^{30}$. Esta misma idea se ha extendido a otros supuestos, como es el caso de la planificación de las diferentes infraestructuras. Tampoco estos planes especiales están vinculados jerárquicamente al instrumento general ${ }^{31}$. A los efectos de la exposición, no es el caso concretamente regulado (si ésta u otra ley lo permite o lo prevé expresamente, es decir, la solución formal). Lo verdaderamente importante es que se admite que un instrumento clásico de desarrollo (un plan especial) puede subsistir autónomamente aunque no exista el planeamiento general, incluso, en contradicción con el mismo. Es más por razón de competencia, el instrumento de «desarrollo» puede ordenar todo ese espacio, mientras el otro instrumento general es incompetente. La solución ya está; de lo que se trata es de generalizarla y reconocer que la vinculación entre el instrumento general y el de desarrollo es más formal que sustantiva.

Esta idea, que rompe con la jerarquía normativa entre planes, y al margen de los casos particulares en los que el legislador lo reconoce, se ha generalizado a modo de principio en algún sistema de planeamiento autonómico (es competencia autonómica la regulación del planeamiento y la relación entre ellos). En tal sentido el artículo 9.3 de la Ley del Suelo y de los Espacios Naturales Protegidos de Canarias dispone: «la invalidez del plan jerárquicamente superior no afectará por sí sola a los planes de desarrollo o instrumentos de gestión que por razón de especialidad y autonomía en el modelo territorial y urbanístico mantengan una autonomía funcional respecto de aquel». En realidad lo que el precepto indica es que en las relaciones entre planes no se pude valorar únicamente el principio de jerarquía, como si se tratara del modelo de la Ley del Suelo de 1956. Al contrario, en línea con los avances legales y doctrinales existentes, su modelo de planeamiento es otro, en el que se da más protagonismo a cada plan en relación al planeamiento superior. Así, para valorar la nulidad de un plan en ese modelo, no se puede aplicar automáticamente la vinculación, sino que habrá que ponderar en qué medida ese plan sería igual aunque no existiera el plan superior. Ello verdaderamente es un cambio que posiblemente veamos convertido en regla general con los años.

b) Posibilidad de modificación de contenidos del planeamiento superior por un instrumento inferior: es una medida de menor intensidad que la primera, pero que cierra el paso también a algunas nulidades. Son varias las leyes que permiten que al menos la ordenación pormenorizada contenida en el planeamiento general se pueda modificar a través de los instrumentos inferiores (planes parciales o especiales). Es decir que la ordenación pormenorizada contenida en el instrumento general no se blinda con la jerarquía de ese plan, pudiendo ser alterada por el instrumento inferior ${ }^{32}$.

${ }^{30}$ Esta idea ya fue desarrollada con anterioridad en otro trabajo, lo que me permite simplificar la exposición, para un mayor detalle GONZÁLEZ SANFIEL, A. (2016): op. cit., págs. 911-924. A nivel normativo, la idea de aprobar el plan especial sin necesidad de plan general de ordenación urbana, por ejemplo, en el artículo 72.5 de la Ley 15/2001, de 14 de diciembre, del Suelo y Ordenación Territorial de Extremadura («podrán formularse también planes especiales...sin necesidad de existencia de Plan General Municipal»). Sobre la planificación de los conjuntos históricos, BARRERO RODRÍGUEZ, Concepción (2006): La ordenación urbanística de los conjuntos históricos, Madrid: lustel, in totum.

${ }^{31}$ Sobre planificación de diversas infraestructuras de uso colectivo cfr. LÓPEZ RAMÓN, F., ESCARTÍN ESDUDÉ, V. (coords.) (2013): Bienes públicos, urbanismo y medioambiente, Madrid: Marcial Pons.

${ }_{32}$ Esta posibilidad se encuentra en un buen número de leyes autonómicas. Puede decirse que a medida que la legislación es más moderna, las posibilidades de modificación van siendo más amplias, frente a las limitaciones iniciales. A título de ejemplo, el artículo Ley 15/2001, de 14 de diciembre, del Suelo y Ordenación Territorial de Extremadura, apoderaba al plan especial para modificar las determinaciones contenidas en el plan general sobre el ámbito en el que se proyecta; por su parte, la legislación andaluza lo circunscribe a los aspectos de la ordenación pormenorizada «potestativa» contenida en el plan general (artículo 13.1b para los planes parciales y 14.3 para los especiales, de la Ley 7/2002, de 17 de diciembre, de Ordenación Urbanística de Andalucía). El artículo 67.2 de la Ley Decreto Legislativo 1/2004, de 22 de abril, por el que se aprueba el texto refundido de las disposiciones legales vigentes en materia de ordenación del territorio y urbanismo del Principado de Asturias, permite a los planes especiales, de manera excepcional, modificar las deter- 
c) Instrumentos «ad hoc» que se imponen al contenido de los planes: dada la complejidad de desarrollar planeamientos generales o realizar sus modificaciones, las diferentes leyes urbanísticas han previstos instrumentos con denominaciones muy distintas cuya finalidad es dar cobertura a actuaciones concretas que pueden desplazar y superponerse al resto de instrumentos, tanto territoriales como urbanísticos, sin necesidad de modificar o adaptar estos últimos para que sean efectivos. Es decir, no quedan condicionados o limitados por la necesidad de adaptación de los instrumentos afectados. En el caso de mantenerse la doctrina general de la nulidad del planeamiento, parece ser que esta es la única salida que se deja frente al planeamiento global, integrador e imposible de que sobreviva con éxito a la vista de los resultados conseguidos ${ }^{33}$.

d) Normas provisionales para evitar la reviviscencia de normas derogadas: se están incorporando al ordenamiento urbanístico, ordenanzas municipales con el valor de planes (p. ej. para afrontar una ordenación menor en una parcela con objeto de facilitar obras de accesibilidad o la ocupación de bienes públicos locales con igual finalidad) ${ }^{34}$. Al margen de la finalidad específica de estas normas, podría valorarse la posibilidad de su utilización también para afrontar provisionalmente el tránsito entre la declaración de nulidad del plan y la elaboración del nuevo plan, todo ello bajo el control judicial correspondiente en ejecución de la sentencia. Una vía no utilizada pero que puede ser usada con la finalidad de no aplicar automáticamente la reviviscencia del planeamiento anterior al anulado, que puede introducir un efecto distorsionador superior.

e) Romper el carácter indisociable plan-acto: junto a tales medidas legales, otro tema, tal y como ha sido apuntado, es el de la desvinculación de los actos administrativos respecto de los planes que lo «aplican», en un sentido similar a lo que hizo la doctrina del Consejo de Estado francés. Aunque por el momento no existe ninguna disposición legal que lo reconozca, esta solución sí se ha valorado en el anteproyecto de reforma de la legislación del suelo y procesal que no fue finalmente aprobada. La solución en cualquier caso, tal y como se indicó, se ha mantenido en Francia por vía interpretativa y separándose de la concepción tradicional o clásica, sin que ello tenga un respaldo normativo expreso. En realidad, en el acto aplicativo existen otro tipo de consideraciones diferentes a los previstos en la norma que, con circunstancias e intereses distintos a los del plan (p. ej. un convenio urbanístico o una reparcelación cuyos términos no se encuentran en el plan). Esos diferentes intereses justifican que se evite proyectar automáticamente los efectos de la nulidad del plan anulado sobre los actos que aparecen en su proceso de ejecución ${ }^{35}$.

\section{LA NECESARIA INTERPRETACIÓN FUNCIONAL DE LOS REQUISITOS FORMALES}

Uno de los mayores focos de nulidades de los planes se debe a la omisión en el procedimiento de alguno de los informes, preceptivos y en la mayoría de los casos vinculantes, que son necesarios a lo largo de la tramitación. Tanto el legislador estatal como los autonómicos establecen, en garantía de las respectivas competencias, la emanación de estos informes cuya omisión o contravención genera la consabida consecuencia anulatoria. Es más, algunas normas se preocupan en enfatizar la declaración de nulidad absoluta o de pleno derecho cuando se omite alguno de los mismos. Esta circunstancia ha sido mayoritariamente rechazada por la doctrina, como algo que no puede seguir sosteniendo y que debe ser corregido.

minaciones del plan general. La Ley 2/2006, de 30 de junio, de Suelo y Urbanismo del País Vasco señala que «Las determinaciones de la ordenación urbanística pormenorizada tendrán el rango jerárquico propio del correspondiente planeamiento de desarrollo» (art. 58.2), de modo que, por ejemplo, «el plan especial de ordenación urbana podrá ser así mismo utilizado para modificar la ordenación pormenorizada del suelo urbano contenida en la documentación del plan general» (art. 70). En un sentido similar, los planes especiales de la legislación catalana pueden modificar los aspectos no fundamentales de la ordenación (art. 67.3 Decreto Legislativo 1/2010, de 3 de agosto, por el que se aprueba el texto refundido de la Ley de urbanismo de Cataluña). La legislación canaria permite a los planes parciales y especiales modificar las determinaciones de la ordenación pormenorizada contenida en el planeamiento general (art. 145.b para los planes parciales y art. 146.4 de la Ley 4/2017, de 13 de julio, del Suelo y de los Espacios Naturales protegidos de Canarias).

33 Sobre estos instrumentos y su configuración MENÉNDEZ REXACH, A. (2016): "Ordenación del territorio supramunicipal y urbanismo municipal: una distinción imposible a la vista de las actuaciones de interés regional", en El derecho de la ciudad..., op. cit., págs. 367-398., VILLAR ROJAS, F. J. (2018): "Los proyectos de interés público: «urbanismo de proyecto» versus «urbanismo de plan»", en Estudios en homenaje al Profesor Luciano Parejo Alfonso, págs. 2.897-2.920 (en prensa). Una manifestación más de este tipo de instrumentos que se superponen a la ordenación territorial y urbanística vigente y que no quedan condicionados por la necesidad de modificar los planes afectados, en la Ley 7/2018, de 2 de agosto, extremeña de grandes instalaciones de ocio (LEGIO).

34 Sobre esta figura, VILLAR ROJAS, F. (2017): "La ordenanza municipal con efectos de plan: un instrumento alternativo de ordenación urbanística", en Los retos actuales del derecho administrativo en el Estado autonómico. Libro Homenaje al profesor José Luis Carro Fernández-Valmayor, Andavira y Fundación Democracia y Administración Local, vol. IV, págs. 679-694.

35 Sobre esta idea IGLESIAS GONZÁLEZ, F. (2018): "Propuestas de reformas normativas para evitar los actuales efectos de la nulidad del planeamiento urbanístico”, en Nulidad de planeamiento y ejecución..., op. cit., págs. $254-262$. 
La situación es si cabe más grave en el ámbito urbanístico, puesto que si bien la jurisprudencia ha admitido la relativización de algunos defectos formales en el procedimiento en relación con la potestad reglamentaria general ${ }^{36}$, esa benevolencia no la ha extendido al enjuiciamiento de los planes territoriales y urbanísticos, en cuya análisis permanece un mayor rigor y exigencia de aquellos requisitos formales. Tal y como se sabe, existen diversas aportaciones doctrinales que expresan la necesidad de un cambio en referencia al tratamiento de los vicios formales, todos ellos tendentes a relativizar las consecuencias invalidantes de los mismos sobre las normas reglamentarias en general y, en particular, sobre el planeamiento ${ }^{37}$.

En realidad la consideración aislada del informe, el que sea, es un planteamiento «egoísta», puesto que el interés que tutela el informe se impone sobre el conjunto de intereses colectivos que están presentes en el plan y que después sirven de base para la creación de nuevos intereses y relaciones. Como los tribunales no son favorables a la suspensión de la eficacia del plan cuando estos se recurren, como ya se conoce, se permite la consolidación de diversas situaciones al amparo del plan impugnado y viciado de nulidad $^{38}$. Al final, ese conjunto de intereses de muy diversa entidad, se ven frustrados porque tal o cual informe no fue emitido. Cuando se anula un plan por tal circunstancia, se desconoce qué importancia real y práctica tiene ese informe en el contenido del plan, si de haberse emitido hubiera sido sustancialmente diferente. Tal y como lo expresa T. R. FERNÁNDEZ «en la mayoría de los casos brilla por su ausencia una valoración de lo que con el vicio apreciado se ha perdido, de lo que hubiera podido variar la decisión final si dicho vicio no se hubiera cometido» ${ }^{39}$. Asimismo, el informe sectorial puede afectar a una parte del plan (la costa, el puerto, la carretera, etc.), sin embargo el efecto invalidante se proyecta sobre todo el conjunto, sin que tenga relación alguna con otros contenidos del plan. El resultado es desproporcionado. El informe únicamente se mira asimismo, al margen de la importancia efectiva que tiene, se lleva por delante todo el plan, es decir, el conjunto de intereses que están presentes en esa ordenación y la base para futuros intereses que se generan al amparo de aquel plan. Todo ello para decir, al final, por ejemplo, que «la ordenación propuesta no afecta al ámbito competencial al que se refiere este informe». Por esta omisión, se anula todo un plan.

Los planteamientos doctrinales que relativizan los vicios formales se han visto reforzados por experiencias de Derecho comparado, que se alejan de una conformación formalista de la relevancia de los vicios. Existe en nuestro país alguna iniciativa normativa que va en esa línea, aunque no en el ámbito urbanístico ${ }^{40}$. A partir de todas esas aportaciones, pueden sentarse las bases para el tratamiento de los vicios formales, en particular, en el caso de los informes. Las bases para superar el talón de Aquiles del planeamiento, ante lo pertinaz de esta causa de nulidad, debe ser:

a) La omisión de un informe no debe ser causa de nulidad, salvo que implique una alteración sustancial del contenido del plan y ello siempre y cuando su estimación no cause un mayor perjuicio para la colectividad.

36 Para una síntesis de la problemática con cita de la doctrina y jurisprudencia correspondiente AGOUÉS MENDIZÁBAL, C. (2017): op. cit, , págs. 364-373. En general sobre la evolución del tratamiento de los vicios formales, GARCÍA LUENGO, J. (2017): Las infracciones formales..., op. cit., in totum.

37 Con este enfoque la importante aportación de LÓPEZ RAMÓN, F. (2018): op. cit., 13-48, que en la línea ya manifestada anteriormente por G. DOMÉNECH PASCUAL (2002) ya citada, en la que se defendía la posibilidad de calificar algunos vicios del reglamento como anulables, pone de relieve que la consideración de todos los vicios formales como causa de nulidad absoluta se debió a una incorrecta interpretación, llevando tales efectos más allá de lo que la propia normativa establecía.

38 De ahí la defensa que realiza en favor de la suspensión, CALVO ROJAS, E. (2011): "Los planes urbanísticos como disposiciones de carácter general. Problemas que suscita la declaración de nulidad de los instrumentos de planeamiento. Suspensión cautelar de la efectividad de los planes impugnados en vía jurisdiccional”, en Administración y justicia: un análisis jurisprudencial. Liber amicorum a Tomás Ramón Fernández, vol. I, Madrid: Civitas, págs. 821-840.

39 FERNÁNDEZ, T. R. (2017): op. cit., pág. 147. En este mismo sentido ya expuse en otro lugar que "si se omite un informe, pero la ordenación materialmente no contraviene la competencia que defiende tal informe, no tendría que tener efecto anulatorio. Si no se afectara de forma real y efectiva la ordenación después de emitirse dicho informe, no debiera producir aquel efecto. Por otra parte, si tuviera una real repercusión debería solo tener un efecto suspensivo respecto de la ordenación del ámbito geográfico al que afecta, pero no respecto de la totalidad del plan. Todo ello con efecto transitorio hasta que sea subsanada su omisión”, GONZÁLEZ SANFIEL, A. M. (2017): op. cit., pág. 454.

40 Me refiero en particular al Anteproyecto de Ley de modificación de la Ley 8/2003, de 22 de diciembre, del procedimiento de elaboración de las disposiciones de carácter general del País Vasco. En su artículo 5 se alude a los vicios de nulidad y anulabilidad del procedimiento (la rúbrica del artículo 5.- es Nulidad y anulabilidad en el procedimiento de elaboración de reglamentos), permitiendo la subsanación y conservación de algunos trámites. Es cierto que en el caso de los informes preceptivos y consultas previas se siguen manteniendo como causa de nulidad absoluta. Pero resulta un avance que se plantee que dentro del ámbito reglamentario no todo es determinante de la nulidad absoluta. Es un paso verdaderamente importante, aunque insuficiente. En cualquier caso, hasta que no se dicte una norma estatal que configure los límites de la declaración de nulidad, tanto general como aplicable al planeamiento, seguirán subsistiendo prácticas e interpretaciones formalista con resultados desproporcionados. 
b) Las declaraciones que reclamen la nulidad de pleno derecho por la omisión de un informe, deben considerarse fórmulas retóricas, puesto que parten de un planteamiento egoísta del valor del informe que se sobrepone a cualquier otra consideración e, incluso, al valor superior que representa el plan en sí mismo. El hecho de que los planes se desenvuelvan el ámbito municipal, no debe desmerecer este planteamiento, puesto que los efectos del plan se van a proyectar sobre un gran número de destinatarios.

c) Un informe que no tiene repercusión sobre todo el contenido del plan, no puede generar una nulidad sobre su integridad. En su caso, sobre la parte a la que afecta, sin perjuicio de su subsanación. En este sentido, un paso en esta línea lo constituye el ejemplo proporcionado por la STSJ de Canarias de 14 de mayo de $2018^{41}$ en relación con el informe preceptivo y vinculante en materia de Costas. El informe se solicitó, pero la Administración aprobó definitivamente el plan antes de que hubieran transcurrido los dos meses desde la solicitud del plan, motivo por el cual se anula éste. Sin embargo, lo llamativo del caso es que esa nulidad no se proyecta sobre todo el plan sino sobre la parte afectada por el informe, lo cual es un cambio sobre el planteamiento tradicional: "aun cuando la jurisprudencia ha resaltado que la omisión de un informe es causa de nulidad de pleno derecho, debe considerarse también que tal omisión debe acarrear la anulación del procedimiento y su reposición al momento oportuno para que pueda suplirse tal falta emitiendo el referido informe. Ponderando ambas afirmaciones en esta caso la nulidad que declaramos no afecta a la totalidad del Plan General impugnado, sino tan solo a la parte que incide sobre el dominio público marítimo-terrestre y sus zonas de servidumbre a fin de que se solicite y emita el informe previsto en el art'. 117.2 de la Ley de Costas». Esto supone un avance sobre la situación actual, en línea con los postulados doctrinales más avanzados en la materia. Esperemos que la solución se afiance y sea aceptada por el Tribunal Supremo.

d) La omisión de informes se podrá subsanar incluso en vía judicial, permitiéndose realizar los ajustes necesarios que pudieran derivarse de la importancia del informe.

Si por vía interpretativa, a pesar de las sólidas bases doctrinales que hoy existen, no se cambia de rumbo, habrá que clarificar normativamente todas esas cuestiones. Todo ello, antes que provocar la nulidad del plan y poner en solfa todas las actuaciones públicas y privadas que se han materializado a su amparo.

\section{EL VALOR NORMATIVO DE LO FÁCTICO A PESAR DE LA NULIDAD DEL PLAN}

Un límite claro a la declaración de nulidad debe ser las situaciones fácticas generadas por el plan anulado. En este caso, se pueden diferenciar varias situaciones, incluso utilizando razonamientos que, en principio, no han sido creados para limitar los efectos de la nulidad. Son situaciones que se imponen, incluso, a lo que el propio plan determina ${ }^{42}$.

Un primer supuesto sería la naturaleza reglada del suelo urbano, tal cual ha sido repetido por la jurisprudencia. Esta doctrina debe servir para limitar los efectos de la declaración de nulidad de los planes. Si lo urbano determina el hecho fáctico de la edificabilidad o la urbanización en un determinado porcentaje, según es definido legislativamente, todo ello incluso con el límite de estar integrado en la malla urbana, es evidente que el plan no puede contradecir esa realidad. Si la contradice debe adaptarse; si se anula, en nada le afecta si se dan las circunstancias previstas normativas. Tal y como sabiamente expusieron E. GARCíA DE ENTERRÍA y T. R. FERNÁNDEZ, «la realidad es siempre una y solo una: no puede ser y no ser al mismo tiempo o ser simultáneamente de una manera y de otra» ${ }^{43}$.

Lo mismo puede decirse del suelo rústico o no urbanizable. Es el propio legislador el que describe las condiciones y características de esta clase de suelo, de ahí que en este caso también la jurisprudencia ha reconocido su carácter reglado.

Esta construcción jurisprudencial se ha gestado para limitar la discrecionalidad del planeamiento a la hora de elaborar el plan ${ }^{44}$. El plan debe clasificar el suelo conforme a las características y condiciones previstas normativamente, al menos en lo que respecta al suelo urbano y a determinadas categorías de suelos rústicos (p. ej. el de protección). Si esto es así, lo que vale para controlar la discrecionalidad debe valer también para limitar los efectos de la declaración de nulidad. Es decir, si una zona tiene la condición de urbana

41 FJ 3. ${ }^{\circ}$ in fine, STSJ de Canarias, núm. 117/2018 (Sala de Gran Canaria) de 14 de mayo de 2018 (núm. de procedimiento 103/2015).

42 GONZÁlEZ SANFIEL, A. M. (2017): op. cit., págs. 434-442.

43 GARCÍA DE ENTERRÍA, E., FERNÁNDEZ, T. R., Curso, T. I, op. cit.,pág. 510.

44 Sobre el control de la discrecionalidad existe una amplia bibliografía, una parte de la más significativa se recoge al final. 
o rústica porque cumple los requisitos legales, la falta de plan no puede desconocer ese hecho. El suelo seguirá siendo urbano o rústico, incluso en contra de lo que diga el plan o si este ha sido anulado.

Esta idea, del valor de lo fáctico, ha venido a reforzarse por la regulación de las situaciones básicas de suelo que realiza la normativa estatal, aunque este no fuera ni su origen ni su finalidad ${ }^{45}$. En esta regulación algo es urbanizado o rural si cumple determinadas condiciones. Lo importante en esta normativa es que la condición de urbanizado o rural se desliga de la clasificación del suelo que realice el planeamiento (cuestión urbanística). Es decir, en el esquema usado por el legislador estatal, puede darse el caso que un plan clasifique un suelo como urbano, pero en realidad no cumpla con las condiciones legales, motivo por el cual se tratará como suelo rural frente a la clasificación del plan; pero puede ser lo contrario un suelo clasificado por el plan como rústico o no urbanizable, que sin embargo esté urbanizado y edificado y, en consecuencia, estaría en la situación básica de suelo urbanizado. Esas situaciones son posibles. Lo determinante en cualquier caso es la realidad, el dato fáctico de la situación del suelo, no su plasmación en el plan a través de la clasificación ${ }^{46}$.

Esta regulación de las situaciones básicas de suelo, en las que puede darse una discordancia entre la realidad (los hechos, la situación básica de suelo) y la clasificación urbanística del plan, unida a la jurisprudencia sobre el carácter reglado tanto del suelo urbano como del suelo rústico, refuerzan la idea: si la realidad se impone al plan, porque aplica conceptos reglados predeterminados normativamente que el mismo debe respetar, también ejercerá su función cuando no hay plan (nulidad), porque la fuerza de los hechos se impondrá.

De esta manera, reforzando la fuerza de los hechos frente a las previsiones del plan, alguna norma autonómica ha clarificado que lo importante en la consideración de urbano de un suelo es precisamente esa realidad, incluso aunque el plan diga otra cosa diferente (esté mal clasificado). Así lo dispone el artículo de la Ley del Suelo y de los ENP de Canarias al establecer que «también es suelo urbano aquel que, aun no estando clasificado por el planeamiento, reúna los presupuestos y las condiciones a que se refieren los anteriores apartados» (art. 46.5), que recoge lo que se entiende materialmente como suelo urbano. Se imponen los hechos (lo sustantivo) frente a la declaración formal del plan. De ahí, a poder utilizar esta idea cuando se produce la nulidad del mismo, no existe mucha dificultad.

El razonamiento expuesto también puede utilizarse en relación con la creación de las infraestructuras o dotaciones colectivas que se han materializado al amparo del plan anulado, calificadas urbanísticamente como sistemas generales o dotacionales según la titularidad o ámbito al que cubren. Evidentemente, la nulidad del plan sobrevenidamente, no hará desaparecer todas esas infraestructuras o espacios colectivos al servicio de la colectividad. Son un dato fáctico también que, el futuro plan previsiblemente recogerá. Pero es más, estas infraestructuras una vez que han sido creadas y puestas en funcionamiento, serán bienes de dominio público afectas al uso o servicio público. La legislación administrativa así define este tipo de bienes, con respaldo igualmente en su configuración constitucional (art. $132 \mathrm{CE}$ ). La afectación, que puede ser un acto jurídico (declaración por ley o acto administrativo), puede también derivar de un dato físico (p. ej. la apertura al tráfico de una vía). Es decir, que tras la anulación del plan se da una realidad que ya no debe buscar su cobertura en el plan anulado, sino en la propia existencia del bien y en la afectación al fin constitucionalmente legítimo que cumple (el uso o servicio público, según la propia jurisprudencia del Tribunal Constitucional) ${ }^{47}$. Este enfoque se obvia en el análisis que se da sobre determinadas infraestructuras al

45 Las situaciones básicas de suelo fueron introducidas por la reforma de la legislación de suelo del año 2007 y se recogen en la actualidad en el artículo 21 del Real Decreto Legislativo 7/2015, de 30 de octubre, por el que se aprueba el Texto Refundido de la Ley de Suelo y Rehabilitación Urbana. Su explicación por parte de PAREJO ALFONSO, L. y ROGER FERNÁNDEZ, G. (2008): Comentarios a la Ley del Suelo, Madrid: lustel, págs. 160-173; MENÉNDEZ REXACH, A. (2008): "Las situaciones básicas de suelo", en El nuevo régimen jurídico del suelo, Madrid: lustel, págs. 117-153; DÍAZ LEMA, J. M. (2008): Nuevo Derecho del Suelo, Madrid: Marcial Pons, págs. 95-104; BAÑO LEÓN, J. M. ${ }^{a}$ (2009): Derecho urbanístico Común, Madrid: Iustel, págs. 110-116; también GUERRERO MANSO, M. ${ }^{a}$ C. (2011): La ciudad existente: delimitación del suelo urbano y en situación de urbanizado, Madrid: lustel.

${ }_{46}$ Los autores que más influencia han tenido en esta figura, PAREJO ALFONSO, L. y ROGER FERNÁNDEZ, G. (2008): Comentarios, op. cit., lo explican de esta manera: «esta distinción se corresponde con la de los medios rural y urbano, descansa simplemente sobre la realidad fáctica constatable y es ajena y previa, por ello, a las diferenciaciones propias de la ordenación territorial y urbanística» (pág. 160). De tal manera, «el suelo urbanizado resulta sin más de un dato objetivo y evidente de la realidad: la integración de los terrenos de que se trate, de forma legal y efectiva, en la red de dotaciones y servicios propios de los núcleos de población. Por ello, la de suelo rural comprende, en negativo, todos los terrenos en los que no se cumpla aquel dato» (pág. 161). Por ello, «todo el mundo de las cosas inmuebles reconducibles al suelo natural y construido es objeto de una summa divisio, al quedar aquéllas colocadas, por efecto de la Ley y en función exclusivamente de su estado efectivo en cada momento, bien en el medio rural, bien en el medio urbano, estando por ello todo el suelo, sin más y necesariamente, en una de las dos situaciones básicas» (pág. 162).

47 Para una explicación de la institución demanial explicando la jurisprudencia sobre la afectación a cualquier fin constitucionalmente legítimo, por todos, MORILLO VELARDE, J. I. (1992): Dominio público, Madrid: Trivium. 
anularse el plan, olvidando las consecuencias propias del carácter demanial del bien. Ni tan siquiera es el carácter indestructible de las obras públicas que utiliza la doctrina francesa. Es simplemente que el bien está vinculado a un fin público, exista o no exista plan. Puede que esa infraestructura en origen tenga su justificación en el plan; pero una vez que está creado y en funcionamiento, como tal realidad afecta a una finalidad pública, adquiere un estatus diferente como bien de dominio público, desligado de las consideraciones urbanísticas que pudieran utilizarse. El bien de dominio público es tal por su titularidad y afectación material al uso o servicio público, al margen o con independencia de su tratamiento urbanístico.

Por ello, también opera, o debería operar, como límite a la declaración de nulidad. Los bienes de dominio público en su configuración constitucional o legal, no se definen y son tales por el tratamiento que tengan en la normativa urbanística, sino porque responden a la definición constitucional o legal de los mismos, lo que trasciende a aquella configuración urbanística y a la propia declaración de nulidad del plan. Los bienes de dominio público son tales con independencia de cómo el sistema urbanístico las haya configurado, por cuanto la clave de su régimen jurídico deriva de la afectación y ésta puede ser tanto jurídica como física o material. La existencia o inexistencia del plan no altera la afectación si verdaderamente se mantiene el fin ${ }^{48}$.

En consecuencia, existen una serie de situaciones fácticas que existen incluso cuando desaparece el plan por su declaración de nulidad. Realidades que tienen su cobertura directamente en los conceptos utilizados por la legislación, sea este por la vía de la clasificación del suelo urbano o rústico, las situaciones fácticas de suelo, o la afectación demanial de conformidad con la definición constitucional o legal de este tipo de bienes. Todo ello lo es con independencia de lo que diga el plan o, de su propia existencia.

\section{EL NUEVO PAPEL DEL JUEZ DE LO CONTENCIOSO}

Cualquier cambio que vaya a introducirse en esta materia, incluso si viene acompañado de un respaldo legal, pasa necesariamente por el papel esencial e ineludible del juez de lo contencioso-administrativo. El éxito de revertir la situación actual exige un cambio legal y jurisprudencial evidente, que vaya en la línea de reforzar el papel del juez.

En unos sistemas, esos poderes han sido previstos normativamente (Alemania o Francia); en otros la capacidad del juez de modular los efectos de las sentencias anulatorias se han visto como una evolución natural del sistema de tutela y justicia (Italia) ${ }^{49}$. Asimismo, la experiencia de los Tribunales constitucionales y europeos nos ha acostumbrado a ver como algo normal la modulación de los efectos anulatorios de la sentencia, bien limitando sus efectos a actos firmes dictados a su amparo, a actos no firmes que pudieran seguir apareciendo de conformidad con la normativa declarada nula o, incluso, permitiendo la aplicación de la norma viciada hasta que se dicte la nueva normativa. De todo ello hay ejemplos.

Toda esta experiencia, comparada, constitucional y europea, sobre el nuevo rol del juez, debe ser aprovechada para afrontar la situación de nulidad de los planes que estamos padeciendo como sociedad. En línea con todas las medidas que ya han sido ensayadas por otros, el juez debe reforzar su papel en orden a afrontar la nulidad no sólo como órgano que constata la ilegalidad, sino que contribuye a reorientar la situación, guiando el proceso para que la situación sea superada.

Las posibilidades son enormes, destacando especialmente la capacidad para subsanar defectos dentro del proceso o la limitación de los efectos de las sentencias sobre otras normas o actos. La anulación parcial sobre determinados ámbitos o la suspensión temporal de efectos sobre los mismos. A ello se suma, la posibilidad de suspensión, ya existente y tan poco usada, que evitaría la consolidación de situaciones irreversibles. El control, incluso, de la aplicación de normas provisionales en tanto se elabore un nuevo plan.

48 Un caso patológico específico lo ha comentado ESPEJO CAMPOS, A. (2017): "Dominio público y BIC como límites a la nulidad en el ámbito urbanístico", en El alcance..., op. cit., págs. 475-485, en relación con la biblioteca del Estado en Las Palmas de Gran Canaria, cuya demolición fue acordada judicialmente porque no se había aprobado un plan especial que había previsto el plan general. No deja de ser paradójico que un país que se encuentra por debajo de la media de la UE en comprensión lectora, se permita el lujo de ordenar la demolición de una biblioteca pública estatal financiada con el dinero de todos. Tras diversos avatares judiciales, finalmente una ley singular declara de utilidad público a efectos expropiatorios los derechos de la sentencia para evitar la demolición (DA 69 de la Ley 48/2015 de Presupuestos Generales del Estado para el año 2016).

49 Sobre la ampliación de los poderes del juez en Italia, AGOSTINO, M. (2013): "L'annullamento condizionato dei provvedimenti amministrativi e l'effetto conformativo della sentenza", en Urbanistica e appalti, núm. 1, págs. 53 y ss.; CARBONE, A. (2013): "Azione di annullamento, ricorso incidentale e perplessità applicative della modulazione degli effetti caducatori", en Diritto Processuale amministrativo, núm. 2, págs. 428-464; en Francia, DELESALLE, H. (2016): "Le place nouvelle du juge administratif dans le droit de l'urbanisme", en Revue de Droit Public, núm. 6, pág. 1.759 (citado por T. R. FERNÁNDEZ). 
Ese refortalecimiento de la posición del juez se debe acompañar de una distinta aplicación de la doctrina de la nulidad sobre los planes. Es decir, no es una ampliación para anular los planes como hasta ahora, sino para corregir y reorientar la situación, permitiendo corregir en sede judicial los vicios que pudieran tener aquellos.

\section{SOBRE LA REFORMA «NON NATA»: LAS TRES «ERRES» DE LA INVALIDEZ}

El anterior Ministro de Fomento llegó a realizar una presentación de una reforma legislativa tendente a limitar los efectos anulatorios de los planes, como medio para incrementar la seguridad jurídica en este ámbito y reaccionar ante la sucesión de sentencias anulatorias de planes de todo tipo. Ello se canalizaría a través de la modificación de algunos preceptos de la ley estatal de suelo, así como la que regula la jurisdicción contencioso-administrativa. No existe un documento oficial, lo cual no obsta para que las ideas o soluciones que proponía dicha reforma sean ya conocidas ${ }^{50}$. Muchos de los remedios que se proponen, acogen planteamientos doctrinales y experiencias que previamente se habían formulado. Los cambios vendrían a operar en tres ámbitos: a) reconsideración de la naturaleza del plan y de las causas de nulidad aplicables a los mismos; b) restricción de las vías impugnatorias de los planes, tanto en lo que afecta a la acción pública como a la impugnación indirecta; c) refortalecimiento de los poderes del juez y del valor de los actos firmes respecto de los planes anulados.

\section{a) Reconsideración de la naturaleza del plan y tratamiento de las causas de nulidad}

La reconsideración de la naturaleza del plan, acoge ciertas posiciones doctrinales previas que habían criticado que «todo» el plan pudiera ser considerado como norma ${ }^{51}$. La mayoría de la doctrina que se ha pronunciado sobre esa cuestión, no cuestiona tanto la naturaleza del plan, sino que todo él en su integridad sea considerado como tal, de modo que lo que se propone es una reducción del ámbito de lo normativo, excluyendo del mismo aquello que realmente no tiene esa naturaleza (estudios, informes, memoria, etc.). En línea con tales planteamientos, el esquema del que se parte es diferenciar el acto aprobatorio del instrumento, que se entiende es un acto administrativo general, de la parte normativa del plan, que se circunscribe a una serie de determinaciones. Es decir, el plan, en el esquema de la reforma que se planteaba, era un acto administrativo general que contenía determinaciones normativas. En línea con ese planteamiento, se diferencia entre la nulidad absoluta de las normas, respecto de la nulidad o anulabilidad de la parte no normativa del plan.

La nulidad absoluta de las normas se dará cuando concurra alguna de las causas de nulidad previstas en el artículo 47.2, esto es, las que afectan específicamente a las normas reglamentarias. En este caso, sin embargo, se introduce como novedad la posibilidad de declarar la nulidad parcial cuando el vicio afecte sólo a determinados preceptos de la disposición o a una parte o área territorial específica. Esto es muy importante en relación con los informes preceptivos y vinculantes, puesto que permitiría valorar en qué medida dicha decisión se proyecta todo el contenido del plan o únicamente sobre una parte, permitiendo restringir los efectos a la parte verdaderamente afectada ( $p$. ej. el informe de costas o sobre determinadas infraestructuras, tales como carreteras, puertos, o informes de patrimonio que afecten únicamente a una parte localizada del plan).

50 Además de las posiciones doctrinales previas para cuestiones específicas, sobre tales propuestas BASSOLS COMA, M. (2017): op. cit., págs. 91-94; BAÑO LEÓN, J. M.a (2017): "Un plan jurídico de reforma para los planes urbanísticos”, en RDUM núm. 311, págs. 53-56; IGLESIAS GONZÁLEZ, F. (2018): op. cit., 231-273); GIFREU FONT, J. (2018): “La reconsideración de la naturaleza normativa de los instrumentos de planeamiento: ¿una panacea para modular el alcance y efectos del dogma de la nulidad absoluta de los reglamentos ilegales?", en Nulidad de planeamiento y ejecución..., op. cit., 54-65.

51 En este sentido destacan las posiciones de BAÑO LEÓN, J. M. ${ }^{a}$ (2009): Derecho urbanístico Común, op. cit., pág. 130; ídem (2016): "Reconsideración sobre el régimen de impugnación del plan urbanístico", en El derecho de la ciudad..., op. cit., págs. 859-864, en la que defiende igualmente el carácter no normativo del aprovechamiento urbanístico (págs. 867-869); ídem (2017), "El plan urbanístico en ruina”, en Práctica urbanística, núm. 144, pág. 2; SANTAMARÍA PASTOR, J. A. (2014): op. cit., pág. 213; IGLESIAS GONZÁLEZ, F. (2015): "Siete medidas urgentes para salvar el urbanismo", en Revista de Derecho Urbanístico y Medioambiente, núm. 301, págs. 121-123; ídem (2018): op. cit., 232-245. En favor de no abandonar la naturaleza jurídica reglamentaria del plan, aunque reconociendo su especialidad, L. PAREJO ALFONSO, después de una fundada argumentación, sostiene que «de la clara especificidad del planeamiento urbanístico no deriva, sin embargo, tanto la estricta necesidad de abandonar su conceptuación como norma reglamentaria, como la de la diferenciación en su seno (en sede legislativa, administrativa y de control judicial) de la diversidad de porte y alcance de las decisiones que en él se agrupan» (2017), "El plan urbanístico no es solo norma. En pro de la superación de la doctrina simplificadora de su naturaleza", en Práctica urbanística, núm. 141, págs. 17-18. Manifestando sus dudas sobre si el cambio de naturaleza jurídica sería la solución, GIFREU FONT, J. (2018): op. cit., págs. 21-65. 
Por otra parte, las causas de nulidad absoluta del acuerdo de aprobación definitiva del plan, se acotan y restringen. En este sentido, la causa «prescindir total y absolutamente del procedimiento legalmente establecido», únicamente se daría cuando se produjera una ausencia total y absoluta de la evaluación ambiental y estratégica (no cuando la hubiera pero se vulnerara algún trámite), cuando exista una «evidente contradicción» de los informes sectoriales respecto de la ordenación cuando ello afecte «de manera sustancial a todo el ámbito" que es objeto de ordenación. Asimismo, cuando existan vicios graves de ponderación material o sustancial entre el modelo elegido y la memoria. En cualquier caso, la nulidad será parcial cuando el vicie afecte a determinaciones concretas o a un ámbito territorial determinado, sin que dicha nulidad pueda extenderse al resto.

Es más, se entiende que los actos administrativos de ejecución y gestión se consideran como independientes del plan que han aplicado. Se evita de este modo el denominado efecto cascada o encadenado, en línea con lo que ya sucede en Francia de conformidad con la doctrina del Consejo de Estado francés.

Se completa el tratamiento de la nulidad, permitiendo la conservación de actos y trámites, pudiendo aplicarse expresamente las técnicas de conversión, conservación y convalidación, en contra de lo que hoy afirma la jurisprudencia.

\section{b) Restricción de las vías impugnatorias}

Otro conjunto de medidas se centran en restringir las posibilidades impugnatorias de los planes. Ello se proyecta, esencialmente, en la acción pública ${ }^{52}$ y la denominada impugnación indirecta.

Respecto de la acción pública, frente a las críticas del uso abusivo que determinada experiencia había arrojado, a) se limita a personas jurídicas sin ánimo de lucro que, a su vez, deben cumplir una serie de requisitos (tener acreditados esos fines en sus estatutos, haber sido creadas con una antelación mínima de dos años); b) los vicios a alegar únicamente pueden ser de naturaleza material o sustantiva (se excluyen los formales que es donde se ha centrado fundamentalmente esta vía); c) se evita la posibilidad de obtener cualquier beneficio económico de su ejercicio cuando se desista del recurso (evitar la práctica de los profesionales de la acción pública que desistían del recurso a cambio de una compensación económica); d) el plazo de impugnación se limita, en línea con las soluciones ya utilizadas en relación con las medidas para el restablecimiento de la legalidad, diferenciando si las obras están en curso de ejecución o están terminadas. En este último caso, el plazo para ejercer la acción será de cuatro años (plazo general para instar el restablecimiento de la legalidad).

En cuanto a la impugnación indirecta, se recoge la doctrina jurisprudencial según la cual por esta vía únicamente se puede alegar vicios sustantivos o materiales, quedando excluidos, en consecuencia, los formales. Asimismo, se limita el plazo para dicha impugnación a cuatro años a partir del día siguiente a la publicación. Transcurrido el mismo ya no cabría la referida impugnación indirecta.

\section{c) Refortalecimiento de los poderes del juez y de los actos firmes}

En este caso, se permite que al tratarse de vicios formales o de procedimiento, la sentencia, fijará un plazo para que la Administración proceda a la subsanación del vicio. En ese tiempo se podrá seguir aplicando de forma provisional el plan o acto anulado, evitando con ello la reviviscencia de la normativa anterior (uno de los efectos típicos de la nulidad del planeamiento). Lo importante es que se permite la subsanación judicial del vicio, lo que viene a completarse con la posibilidad, ya citada, de la conservación de trámites y actos.

En la misma línea, la reforma refuerza el valor de los actos firmes, una de las previsiones ya contenidas en el artículo $73 \mathrm{LJ}$ y del que la jurisprudencia ha realizado una amplia aplicación. La novedad vendría por aclarar que la nulidad no conllevaría la nulidad de los planes de desarrollo, salvo que la sentencia así lo declare expresamente por estar afectados por los mismos vicios. En este último caso, se debería hacer un mayor esfuerzo por clarificar esta limitación, para evitar que interpretaciones formalistas vengan nuevamente a limitar los efectos de una previsión similar.

52 Las críticas a la perversión que ha generado la acción pública se han extendido. En este sentido, J. M. ${ }^{a}$ BAÑO LEÓN habla del sinsentido de la acción pública (2016, op. cit., págs. 868-870); T. R. FERNÁNDEZ alude a los profesionales de la misma que han contribuido a generar más corrupción (2017, op. cit., pág. 158); F. IGLESIAS GONZÁLEZ propone su limitación temporal (2018, op. cit., págs. 274-278). 
Las expuestas son medidas que, tal y como se ha adelantado, de alguna u otra manera se han venido valorando doctrinalmente, sin perjuicio de contar con apoyo en otros sistemas. De convertirse finalmente en norma y aplicarse, cambiaría sustancialmente el panorama actual. Sin duda, romper con la idea de encadenamiento o ligazón entre el plan superior y los planes de desarrollo, así como de los actos administrativos que los aplican, sería una novedad de una fuerza extraordinaria, puesto que rompería con la nulidad en cascada o encadenada que tanta inseguridad jurídica está generando. Por el momento son únicamente ideas o propuestas que se están valorando, todas con el objeto de poner coto a la anulación masiva de planes y actos en materia urbanística.

\section{UN CAMBIO ESTÁ LLEGANDO}

Nadie destruye aquello que representa un gran valor. Sin embargo, los planes pese a conciliar un conjunto de intereses contrapuestos y complejos, son fácilmente anulados. Se pueden impugnar directa e indirectamente. Existe la acción pública. Siempre hay algún requisito que no se ha cumplido. Cualquier infracción determina la nulidad. Esta, a su vez, se proyecta sobre todos los actos jurídicos que lo han aplicado. El vacío que genera la declaración de nulidad condiciona el presente y futuro de la ciudad, de los ciudadanos, de los empresarios. Una parálisis que genera inseguridad, retracción económica, pérdida de inversión y de riqueza. En fin, falta de credibilidad en el Derecho como certidumbre. Si todo puede ser subvertido muchos años más tarde de la aprobación de los planes (incluso décadas más tarde), haciendo que todo quede cuestionado en un sinfín de consecuencias imprevisibles, nada hemos ganado como sistema jurídico.

El reconocimiento del valor que encierra un plan, debe ser objeto de protección, más allá de los problemas formales o algunos de los incumplimientos que se hayan podido cometer en el proceso largo, complejo y tortuoso de su elaboración. ¿Por qué es más importante proteger un informe, que la protección de la confianza generada en miles de ciudadanos de un plan-norma aprobada por la Administración? ¿Por qué recaen las consecuencias de la nulidad de dicha norma sobre los ciudadanos que no han participado en la generación del vicio determinante de la nulidad? Una parte del todo (informe), no puede o no debería tener consecuencias sobre el conjunto (el plan). Hoy el plan cae y todo lo hecho queda patas arriba. ¿Es bueno para el país en su conjunto que los planes de las principales ciudades estén en entredicho? Ver el problema desde una perspectiva local o autonómica, hace perder de vista la amplitud del problema económico, social y jurídico al que nos enfrentamos como sociedad. Porque ya no se trata de si este u otro municipio se encuentra colapsado.

Si sumamos todos y cada uno de los planes de las diferentes ciudades y todos y cada uno de los planes de desarrollo y derivados de se han aprobado; si somos conscientes de la cantidad de actos jurídicos que se han ido generando con los años al amparo de dichos planes, en el conjunto del país, es una situación verdaderamente para temblar. Evidentemente, los efectos anulatorios de los planes no se quedan en el plan en sí mismo: se proyectan sobre el sector económico y social del municipio. Y si sumamos todos los municipios españoles afectados, el efecto negativo global es preocupante. Ya no se trata de que este estudio de detalle o aquel plan parcial sean ilegales, es que se está cuestionando el entero sistema y forma de planificación en su conjunto, lo que repercute sobre el tejido económico y social del país ¿Cuánta inversión económica, tributos o puestos de trabajo se han perdido por la situación de incertidumbre generada por la anulación de los planes? Ojalá que nunca lo sepamos. Pero lo que sí se puede hacer, tal y como lo han hecho otros países y lo propone a gritos la doctrina, es poner orden y reconducir la situación.

Otros sistemas jurídicos se han dado cuenta hace tiempo, que el valor que aporta el plan en sí mismo, así como los diversos actos que lo han aplicado (licencia de obras, por ejemplo), debe de ser tutelado y protegido por encima de las irregularidades aisladamente consideradas.

Al entrar en la basílica de San Pedro en el Vaticano, a mano derecha puede contemplarse La piedad de Miguel Ángel. Hace años que, después de haber sufrido una agresión y tras haberla restaurado, han colocado una pantalla protectora para impedir nuevos ataques, debido al valor único que aquella escultura atesora. Los planes territoriales y urbanísticos, pese al extraordinario valor que tienen, se encuentran, se podría decir que a la intemperie, sin medidas protectoras que impidan su destrucción en términos jurídicos, circunstancia esta que se produce a través de la declaración de su nulidad. Esperemos que los planes, sin llegar a la excelencia y magnificencia de aquella escultura, tengan un mejor tratamiento en el futuro. Lo agradecerá el conjunto de la sociedad y de la economía global de nuestro país. 
DA. Nueva Época - N. ${ }^{\circ}$ 5, enero-diciembre 2018 - ISSN: 1989-8983 - DOI: 10.24965/da.v0i5.10607 - [Págs. 46-68]

Nulidad del planeamiento urbanístico e invalidez de los actos amparados en el mismo. Atención especial a las nuevas..

Andrés M. González Sanfiel (España)

\section{BIBLIOGRAFÍA}

AA.VV. (2009): El control de la legalidad urbanística. El Estatuto básico del empleado público, Sevilla: Instituto Andaluz de Administración Pública, 355 págs.

AGOSTINO, MEALE (2013): "L'annullamento condizionato dei provvedimenti amministrativi e l'effetto conformativo della sentenza", en Urbanistica e appalti, núm. 1, págs. 53-57.

AGOUÉS MENDIZÁBAL, CARMEN (2014): "Los efectos de las sentencias que declaran la nulidad de las disposiciones administrativas de carácter general”, en Revista Vasca de Administración Pública, núm. especial 99100. Homenaje a Demetrio Loperena y Ramón Martín Mateo, págs. 65-85.

AGOUÉS MENDIZÁBAL, CARMEN (2017): "La modulación de los efectos de la invalidez de los reglamentos", en LÓPEZ RAMÓN, FERNANDO, VILLAR ROJAS, FRANCISCO J. (coords.), El alcance de la invalidez de la actuación administrativa, Actas del XII Congreso de la Asociación Española de Profesores de Derecho Administrativo, Madrid: AEPDA-INAP, págs. 361-410.

AGUDO GONZÁLEZ, JORGE (coord.) (2018): Nulidad de planeamiento y ejecución de sentencias, Barcelona: Bosch editor, 304 págs.

AUBY, JEAN BERNARD, PÉRINET-MARQUET, HUGUES, NOGUELLOU, ROZEN (2012): Droit de l'urbanisme et de la construction, 9. ${ }^{a}$ ed., Paris: Montcherestien, 1.248 págs.

BAÑO LEÓN, JOSÉ MARÍA (2009): Derecho urbanístico común, Madrid: lustel, 564 págs.

BAÑO LEÓN, JOSÉ MARÍA (2016): "Reconsideración sobre el régimen de impugnación del plan urbanístico", en El derecho de la ciudad y el territorio. Estudios en homenaje a Manuel Ballbé Prunes, Madrid: INAP, págs. 859-871.

BAÑO LEÓN, JOSÉ MARÍA (2017): "El plan urbanístico en ruina”, en Práctica urbanística, núm. 144, 8 págs.

BAÑO LEÓN, JOSÉ MARÍA (2017): “Un plan jurídico de reforma para los planes urbanísticos”, en RDUM, núm. 311, págs. 43-56.

BARRERO RODRÍGUEZ, CONCEPCIÓN (2006): La ordenación urbanística de los conjuntos históricos, Madrid: lustel, 344 págs.

BASSOLS COMA, MARTÍN (2007): "Panorama del Derecho urbanístico comparado", en Serie Claves del Gobierno Local, núm. 5, Fundación Democracia y Gobierno Local, págs. 11-25.

BASSOLS COMA, MARTÍN (2017): "La asimilación de los planes de urbanismo a normas reglamentarias y problemática jurídica de su anulación”, en SORIA MARTÍNEZ, GABRIEL, BASSOLS COMA, MARTÍN (coords.): Los efectos de la nulidad de los instrumentos de planeamiento urbanístico, Madrid: Thomson Reuters-Aranzadi, págs. 27-102.

BELADÍEZ ROJO, MARGARITA (1994): Validez y eficacia de los actos administrativos, Madrid: Marcial Pons, 384 págs.

BUONFINO, ALBERTO (2014): "La disciplina della nullità provvedimentale nel sistema amministrativo tedesco: spunti per un'analisi di Diritto comparato", en Diritto Amministrativo, núm. 4, págs. 777-805.

BOUYA, DRISS (2017): Le plan local d'urbanisme à l'épreuve de la hiérarchie des normes, These de doctorat de L'Université de Lyon, https://tel.archives-ouvertes.fr/tel-01799567.

CALEGARI, ALESSANDRO (2012): L'invalidità derivata nei rapporti tra atti amministrativi, Milano: Cedam, 366 págs.

CALVO ROJAS, EDUARDO (2011): "Los planes urbanísticos como disposiciones de carácter general. Problemas que suscita la declaración de nulidad de los instrumentos de planeamiento. Suspensión cautelar de la efectividad de los planes impugnados en vía jurisdiccional", en Administración y justicia: un análisis jurisprudencial. Liber amicorum a Tomás Ramón Fernández, vol. I, Madrid: Civitas, págs. 821-840.

CANO CAMPOS, TOMÁS (2004): La invalidez sobrevenida de los actos administrativos, Madrid: Thomson-Civitas, 382 págs.

CARBONE, ANDREA (2013): "Azione di annullamento, ricorso incidentale e perplessità applicative della modulazione degli effetti caducatori”, en Diritto Processuale amministrativo, núm. 2, págs. 428-464.

CASANOVA GÓMEZ, CARMEN (2014): "La restauración del plan general de ordenación urbana de Madrid, tras la anulación parcial por resoluciones judiciales o la perpetua intirinidad del planeamiento general en nuestro país", en Revista de Derecho Urbanístico y Medioambiente, núm. 287, págs. 35-89.

CORDÓN MORENO, FAUSTINO (2013): La revisión de oficio de los actos administrativos y disposiciones de carácter general y su control jurisdiccional. Un estudio desde la jurisprudencia, Madrid: Civitas-Thomson Reuters, 183 págs.

DELESALLE, HUBERT (2016): "Le place nouvelle du juge administratif dans le droit de l'urbanisme", en Revue de Droit Public, núm. 6, pág. 1.759.

DELGADO BARRIO, JAVIER (2016): El control de la discrecionalidad del planeamiento urbanístico, 2. ${ }^{\text {a }}$ ed., Madrid: Civitas, 121 págs.

DESDENTADO DAROCA, EVA (1996): Discrecionalidad administrativa y planeamiento urbanístico, 2. ${ }^{a}$ ed., Madrid: Aranzadi, 533 págs.

DÍAZ LEMA, JOSÉ MANUEL (2008): Nuevo Derecho del Suelo, Madrid: Marcial Pons, 389 págs.

DOMÉNECH PASCUAL, GABRIEL (2002): La invalidez de los reglamentos, Valencia: Tirant lo Blanch, 558 págs.

DOMÍNGUEZ BLANCO, JOSÉ MARÍA (2016): "Los límites a la acción de nulidad de títulos habilitantes", en Revista de Derecho Urbanístico y Medioambiente, núm. 305, págs. 17-77. 
DA. Nueva Época - N. ${ }^{5}$, enero-diciembre 2018 - ISSN: 1989-8983 - DOI: 10.24965/da.v0i5.10607 - [Págs. 46-68]

Nulidad del planeamiento urbanístico e invalidez de los actos amparados en el mismo. Atención especial a las nuevas..

Andrés M. González Sanfiel (España)

ESPEJO CAMPOS, ALICIA (2017): "Dominio público y BIC como límites a la nulidad en el ámbito urbanístico", en LÓPEZ RAMÓN, FERNANDO, VILLAR ROJAS, FRANCISCO J., El alcance de la invalidez de la actuación administrativa, Actas del XII Congreso de la Asociación Española de Profesores de Derecho Administrativo, Madrid: AEPDA-INAP, págs. 475-485.

FERNÁNDEZ SALMERÓN, MANUEL (2002): El control jurisdiccional de los reglamentos. Procedimiento administrativo, proceso judicial y potestad reglamentaria, Barcelona: Atellier, 463 págs.

FERNÁNDEZ TORRES, JUAN RAMÓN (2013): "Renovación del derecho urbanistico en Francia y obligación de apertura de un proceso de debate y reflexión en España”, en Revista de Urbanismo y Edificación, núm. 29, págs. 9-11.

FERNÁNDEZ, TOMÁS RAMÓN (2003): "La distinción entre suelo urbano consolidado y no consolidado en la sentencia constitucional 54/2002, de 27 de febrero", en Revista de Urbanismo y Edificación, núm. 7, págs. 91-94.

FERNÁNDEZ, TOMÁS RAMÓN (2013): "Proceso contencioso-administrativo: semejanzas y diferencias de los casos francés y español”, en Revista de Urbanismo y Edificación, núm. 29, págs. 77-95.

FERNÁNDEZ, TOMÁS RAMÓN (2016): Manual de Derecho urbanístico, 24. ${ }^{a}$ ed., Madrid: Civitas-Thomson Reuters, 248 págs.

FERNÁNDEZ, TOMÁS RAMÓN (2017): "El contencioso urbanístico y su necesaria reforma”, en Revista de Administración Pública, núm. 203, págs. 137-162. DOI: 10.18042/cepc/rap.203.04.

GARCÍA DE ENTERRÍA, EDUARDO (1989): "Un paso importante para el desarrollo de nuestra justicia constitucional: la doctrina prospectiva en la declaración de ineficacia de las Leyes inconstitucionales”, en Revista Española de Derecho Administrativo, núm. 61, págs. 5-16.

GARCÍA DE ENTERRÍA, EDUARDO (1998): "El Derecho urbanístico español a la vista del siglo XXI", en Revista Española de Derecho Administrativo, núm. 99, págs. 395-403.

GARCÍA DE ENTERRÍA, EDUARDO, FERNÁNDEZ, TOMÁS RAMÓN (2015): Curso de Derecho Administrativo. I, 17. a ed., Madrid: Civitas-Thomson Reuter, 867 págs.

GARCÍA DE ENTERRÍA, EDUARDO, PAREJO ALFONSO, LUCIANO (1979): Lecciones de Derecho urbanístico. I, Madrid: Civitas, 459 págs.

GARCÍA LUENGO, JAVIER (2017): Las infracciones formales como causa de invalidez del acto administrativo. Un estudio sobre el artículo 48.2 de la Ley 39/2015, lustel, 222 págs.

GEIS I CARRERAS, GEMMA (2013): La ejecución de las sentencias urbanísticas, 2. ${ }^{a}$ ed., Barcelona: Atellier, 436 págs.

GIFREU FONT, JUDITH (2017): "Los efectos jurídicos de la anulación del planeamiento urbanístico sobre los actos singulares de aplicación. Especial referencia a los instrumentos de ejecución y títulos administrativos habilitantes dictados a su amparo", en SORIA MARTÍNEZ, GABRIEL, BASSOLS COMA, MARTÍN (coords.): Los efectos de la nulidad de los instrumentos de planeamiento urbanístico, Madrid: Thomson Reuters-Aranzadi, págs. 145-228.

GIFREU FONT, JUDITH (2018): "La reconsideración de la naturaleza normativa de los instrumentos de planeamiento: ¿una panacea para modular el alcance y efectos del dogma de la nulidad absoluta de los reglamentos ilegales?”, en AGUDO GONZÁLEZ, JORGE (coord.) (2018): Nulidad de planeamiento y ejecución de sentencias, Barcelona: Bosch editor, págs. 21-65.

GIFREU FONT, JUDITH, BASSOLS COMA, MARTÍN, MENÉNDEZ REXACH, ÁNGEL (2016): El derecho de la ciudad y el territorio. Estudios en homenaje a Manuel Ballbé Prunes, Madrid: INAP, 1.043 págs.

GIOVAGNOLI, ROBERTO, MORELI, SABRINA (2014): Urbanistica e governo del territorio. Normativa e giurisprudenza ragionata, Milano: Giuffrè Editore, 492 págs.

GÓMEZ-FERRER MORANT, RAFAEL (1977): "Nulidad de Reglamentos y actos dictados durante su vigencia", en Revista Española de Derecho Administrativo, núm. 14, págs. 387-400.

GONZÁLEZ SANFIEL, ANDRÉS M. (2011): “Invalidez sobrevenida de los actos de aplicación del planeamiento urbanístico nulo", en Estudios sobre planeamiento territorial y urbanístico, Valencia: Tirant lo Blanch, págs. 285307.

GONZÁLEZ SANFIEL, ANDRÉS M. (2016): “El principio de especialidad como límite a la declaración de nulidad del planeamiento", en BASSOLS COMA, MARTÍN, MENÉNDEZ REXACH, ÁNGEL, GIUFREU, JUDITH (coords.), El derecho de la ciudad y el territorio. Libro homenaje a Manuel Ballbé Prunés, Madrid: INAP, págs. 911-924.

GONZÁLEZ SANFIEL, ANDRÉS M. (2017): "Límites a la declaración de nulidad del planeamiento", en LÓPEZ RAMÓN, FERNANDO, VILLAR ROJAS, FRANCISCO J. (coords.), El alcance de la invalidez de la actuación administrativa, Actas del XII Congreso de la Asociación Española de Profesores de Derecho Administrativo, Madrid: AEPDA-INAP, págs. 411-459.

GUERRERO MANSO, MARÍA DEL CARMEN (2011): La ciudad existente: delimitación del suelo urbano y en situación de urbanizado, Madrid: lustel, 263 págs.

IGLESIAS GONZÁLEZ, FELIPE (2015): "Siete medidas urgentes para salvar el urbanismo", en Revista de Derecho Urbanístico y Medioambiente, núm. 301, págs. 77-149.

IGLESIAS GONZÁLEZ, FELIPE (2018): "Propuestas de reformas normativas para evitar los actuales efectos de la nulidad del planeamiento urbanístico", en AGUDO GONZÁLEZ, JORGE (coord.) (2018): Nulidad de planeamiento y ejecución de sentencias, Barcelona: Bosch editor, págs. 231-278.

LACAVA, FILIPPO (2015): Principio di legalità dell'azione amministrativa ed esigenze di risultato, Roma: Aracne Editrice, 456 págs. 
DA. Nueva Época - N. ${ }^{\circ}$, enero-diciembre 2018 - ISSN: 1989-8983 - DOI: 10.24965/da.v0i5.10607 - [Págs. 46-68]

Nulidad del planeamiento urbanístico e invalidez de los actos amparados en el mismo. Atención especial a las nuevas..

Andrés M. González Sanfiel (España)

LÓPEZ RAMÓN, FERNANDO (2011): "El principio de no regresión en la clasificación de los espacios naturales protegidos en el Derecho español”, en Revista Aranzadi de Derecho Ambiental, núm. 20, págs. 13-27.

LÓPEZ RAMÓN, FERNANDO (2013): Introducción al Derecho urbanístico, 4. ${ }^{a}$ ed., Madrid: Marcial Pons, 255 págs.

LÓPEZ RAMÓN, FERNANDO (2018): "La calificación de los vicios de los reglamentos", en Revista de Administración Pública, núm. 205, págs. 13-48. DOI: 10.18042/cepc/rap.205.01.

LÓPEZ RAMÓN, FERNANDO, ESCARTÍN ESDUDÉ, V. (coords.) (2013): Bienes públicos, urbanismo y medioambiente, Madrid: Marcial Pons, 612 págs.

LÓPEZ RAMÓN, FERNANDO, VILLAR ROJAS, FRANCISCO J. (2017): El alcance de la invalidez de la actuación administrativa, Actas del XII Congreso de la Asociación Española de Profesores de Derecho Administrativo, Madrid: AEPDA-INAP, 706 págs.

MARTÍN REBOLLO, LUIS (2009): "El planeamiento municipal: perspectiva general”, en Fundamentos de Derecho urbanístico. I, Madrid: Aranzadi-Thomson Reuters, págs. 249-259.

MARTÍN REBOLLO, LUIS, BUSTILLO BOLADO, ROBERTO (2009): Fundamentos de Derecho urbanístico. I, Madrid: Aranzadi-Thomson Reuters, 1.004 págs.

MENÉNDEZ REXACH, ÁNGEL (2008): “Las situaciones básicas de suelo”, en El nuevo régimen jurídico del suelo, Madrid: lustel, págs. 117-153.

MENÉNDEZ REXACH, ÁNGEL (2016): "Ordenación del territorio supramunicipal y urbanismo municipal: una distinción imposible a la vista de las actuaciones de interés regional", en BASSOLS COMA, MARTÍN, MENÉNDEZ REXACH, ÁNGEL, GIUFREU, JUDITH (coords.), El derecho de la ciudad y el territorio. Libro homenaje a Manuel Ballbé Prunés, Madrid: INAP, págs. 367-398.

MENGOLI, GIAN CARLO (2014): Manuale di Diritto urbanistico, $7 .^{a}$ ed., Milano: Giuffrè Editore, 1.188 págs.

MERELO ABELA, JOSÉ MANUEL (2011): Urbanismo y justicia, Madrid: La Ley-El consultor de los Ayuntamientos, 744 págs.

MORILLO-VELARDE PÉREZ, JOSÉ IGNACIO (1992): Dominio público, Madrid: Trivium, 156 págs.

MUÑOZ MACHADO, SANTIAGO (2006): Tratado de Derecho Administrativo y Derecho público general. II, Madrid: lustel, 1.405 págs.

MUÑOZ MACHADO, SANTIAGO, LÓPEZ BENÍTEZ, MARIANO (2009): El planeamiento urbanístico, Madrid: lustel, 268 págs.

ORTEGA MORILLO, GABRIEL (2018): La nulidad del planeamiento general urbanístico. Guía práctica para anular un PGOU, Madrid: Sepin, 122 págs.

PARDO ÁLVAREZ, MARÍA (2005): La potestad de planeamiento urbanístico bajo el Estado social, autonómico y democrático de Derecho, Madrid: Marcial Pons, 671 págs.

PAREJO ALFONSO, LUCIANO (2013): "La ordenación urbanística en Alemania (Parte I)", en Revista de Derecho urbanístico y medioambiente, núm. 281, págs. 13-82.

PAREJO ALFONSO, LUCIANO (2013): "La ordenación urbanística en Alemania (Parte II)", en Revista de Derecho urbanístico y medioambiente, núm. 282, págs. 13-77.

PAREJO ALFONSO, LUCIANO (2015): “Derecho urbanístico francés (Parte I)", en Revista de Derecho urbanístico y medioambiente, núm. 301, págs. 17-76.

PAREJO ALFONSO, LUCIANO (2015): “Derecho urbanístico francés (Parte II)”, en Revista de Derecho urbanístico y medioambiente, núm. 302, págs. 17-69.

PAREJO ALFONSO, LUCIANO (2017): "El plan urbanístico no es solo norma. En pro de la superación de la doctrina simplificadora de su naturaleza", en Práctica urbanística, núm. 141, 35 págs.

PAREJO ALFONSO, LUCIANO, ROGER FERNÁNDEZ, GERARDO (2008): Comentarios a la Ley del Suelo, Madrid: lustel, 441 págs.

RAMOS MEDRANO, JOSÉ ANTONIO (2015): "Los 10 errores más básicos y frecuentes en el urbanismo español", en Actualidad jurídica ambiental, núm. 52, págs. 3-26.

RAMOS MEDRANO, JOSÉ ANTONIO (2017): "Más de 90 planes de urbanismo anulados judicialmente por no justificar la disponibilidad de recursos hídricos", en Actualidad jurídica ambiental, núm. 67, págs. 4-24.

REBOlLO PUIG, MANUEL (1998): "Artículo 73", en Revista Española de Derecho Administrativo, núm. 100 extra dedicado a la LJ, págs. 518-537.

RENAU FAUBELL, FERNANDO (2016): "Nulidad radioactiva de los planes urbanísticos por defectos en el procedimiento de aprobación", en Noticias Jurídicas accesible en abierto.

RODRÍGUEZ DE SANTIAGO, JOSÉ MARÍA (1998): "Líneas básicas de la legislación urbanística de la República Federal de Alemania”, en Revista de Derecho urbanístico y medioambiente, núm. 163, págs. 29-62.

SANTAMARÍA PASTOR, JUAN ALFONSO (1975): La nulidad de pleno derecho de los actos administrativos: contribución a una teoría de la ineficacia en el Derecho Público, 2. ${ }^{a}$ ed., Madrid: IEA, 484 págs.

SANTAMARÍA PASTOR, JUAN ALFONSO (2014): "Muerte y transfiguración de la desviación de poder: sobre las sentencias anulatorias de planes urbanísticos", en Revista de Administración Pública, núm. 195, págs. 197-215.

SANTAMARÍA PASTOR, JUAN ALFONSO (2016): "El nuevo régimen de la revisión de oficio y de los recursos administrativos", en Revista Vasca de Administración Pública, núm. 105, págs. 247-273.

SAVARIT-BOURGEOIS, ISABELLE (2014): Droit de l'Urbanisme, Gualino. 
SCHMIDT-ABMANN, EBERHARD (2011): "L'illegittiità degli atti amministrativi per vizi di forma del procedimento e la tutela del cittadino”, en Diritto Amministrativo, núm. 3, págs. 471-497.

SORIA MARTÍNEZ, GABRIEL, BASSOLS COMA, MARTÍN (coords.) (2017): Los efectos de la nulidad de los instrumentos de planeamiento urbanístico, Madrid: Thomson Reuters-Aranzadi, 495 págs.

STELLA RICHTER, PAOLO (2016): Diritto urbanistico, $4 .^{a}$ ed., Milano: Giuffrè Editore, 154 págs.

SUAY RINCÓN, JOSÉ (2015): "Planeamiento urbanístico y recursos hídricos. Condicionantes formales y materiales", en Planificación y ordenamiento jurídico de los recursos hídricos, Colección Derecho de Aguas 4, Fundación Agbar-Consejo General del Poder Judicial, págs. 21-100.

TESSARO, TIZIANO, PIOVESAN, STEFANIA (2015): La riforma Madia del procedimento amministrativo. La legge 241/90 dopo la legge 124/2015, Santarcangelo di Romagna: Maggioli Editore, 326 págs.

TORNOS MÁS, JOAQUÍN (1982): "De nuevo sobre el control de los Decretos legislativos: la declaración de nulidad, por vicios de carácter procedimental, del Decreto de 20 de diciembre de 1974, en materia de disciplina de mercado", en Revista Española de Derecho Administrativo, núm. 32, págs. 885-894.

TRAYTER JIMÉNEZ, JUAN MANUEL (1996): El control del planeamiento urbanístico, Madrid: Civitas, 628 págs.

VILLAR EZCURRA, JOSÉ LUIS (1979): “En torno a la naturaleza jurídica de los planes de urbanismo", en Revista de Derecho urbanístico, núm. 64, págs. 13-93.

VILLAR ROJAS, F. (2017): "La ordenanza municipal con efectos de plan: un instrumento alternativo de ordenación urbanística", en Los retos actuales del derecho administrativo en el Estado autonómico. Libro Homenaje al profesor José Luis Carro Fernández-Valmayor, Andavira y Fundación Democracia y Administración Local, IV, págs. 679-694.

VILLAR ROJAS, F. (2018): "Los proyectos de interés público: «urbanismo de proyecto» versus «urbanismo de plan»", en Estudios en homenaje al Profesor Luciano Parejo Alfonso, págs. 2.897-2.920 (en prensa). 